\title{
Structure-based drug design of potent pyrazolic derivatives against rhinovirus replication
}

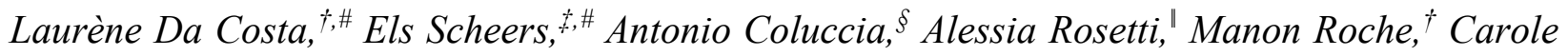
Di Giorgio, ${ }^{L}$ Johan Neyts,,$^{\star}$ Thierry Terme, ${ }^{\dagger}$ Roberto Cirilli, ${ }^{,}$Giuseppe La Regina, ${ }^{\S}$ Romano Silvestri, ${ }^{\S}$ Carmen Mirabelli, ${ }^{\ddagger}$ Patrice Vanelle. ${ }^{\dagger * *}$

$\dagger$ Aix-Marseille Univ, Institut de Chimie Radicalaire, Laboratoire de Pharmacochimie Radicalaire, UMR 7273 CNRS, 27 Boulevard Jean Moulin, 13385 Marseille Cedex 05, France.

$\$$ KU Leuven-University of Leuven, Department of Microbiology and Immunology, Rega Institute for Medical Research, Laboratory of Virology and Chemotherapy, B-3000 Leuven, Belgium.

$\S$ Department of Drug Chemistry and Technologies, Sapienza University of Rome, Laboratory affiliated to Istituto Pasteur Italia-Fondazione Cenci Bolognetti, Piazzale Aldo Moro 5, I-00185 Roma, Italy.

"Centro nazionale per il controllo e la valutazione dei farmaci, Istituto Superiore di Sanità, Viale Regina Elena 299, I-00161 Roma, Italy.

${ }^{\text {L }}$ Aix-Marseille Univ, CNRS, IRD, Avignon Université, IMBE UMR 7263, Laboratoire de Mutagénèse Environnementale, 27 Boulevard Jean Moulin, 13385 Marseille Cedex 05, France. 
KEYWORDS: RV, VP1 protein, capsid binder, chiral inhibitors, heterocycles.

ABSTRACT: Rhinoviruses (RVs) have been recently associated with exacerbations of many pulmonary diseases, thus increasing morbidity and/or mortality in subjects at risk. Unfortunately, the wide variety of RV genotypes constitutes a major hindrance for the development of rhinovirus replication inhibitors. In the current investigation, we develop a novel series of pyrazolic derivatives that potently inhibits rhinovirus replication. Compounds $\mathbf{1 0 e}$ and $\mathbf{1 0 h}$ act as early stage inhibitors of rhinovirus infection with a broad-spectrum activity against RV-A and RV-B species $\left(\mathrm{EC}_{50}<0.1 \mu \mathrm{M}\right)$. We have also evaluated the dynamics of resistance emergence of these promising compounds and their in vitro genotoxicity. Molecular docking experiments shed light on the pharmacophoric elements interacting with residues of the drug-binding pocket.

\section{INTRODUCTION}

Rhinoviruses (RVs) are among the most common viruses worldwide. With a respiratory tract tropism, these infectious agents of the Picornaviridae family (genus Enterovirus) are the major causative agents of upper respiratory tract infections. ${ }^{1,2}$ Besides being the etiological agent of the "common cold", they are also associated with acute otitis media (AOM) development in pediatric populations, ${ }^{3,4,5}$ and sinusitis. ${ }^{6,7}$ Since a decade, RVs are known to cause exacerbations of chronic pulmonary diseases in infants, elderly, and immunocompromised patients. ${ }^{8,9}$ RVs have a strong impact on the morbidity and the mortality related to asthma in these populations. ${ }^{10,11,12,13}$ Also, it has been reported that RV infections lead to worsening of chronic obstructive pulmonary disease (COPD), ${ }^{14,15}$ and cystic fibrosis. ${ }^{16,17} \mathrm{Up}$ to date, more than three hundred million people are suffering from chronic pulmonary illnesses. Industrial and academic 
laboratories are therefore reviving research against rhinoviruses in order to provide therapeutic solutions.

As commonly observed in the Picornavirales order, RVs are composed of a positive-sense single-stranded RNA surrounded with a protein shell called the capsid. To date, 167 types of rhinovirus have been identified by molecular-based phylogenetics and classified in three species, namely RV-A, RV-B, and RV-C. ${ }^{18,19}$ Following entry, viral RNA is translated into a single polyprotein, which is further processed into four structural and seven non-structural proteins required for the replication. The structural proteins (VP1-VP4) form the characteristic icosahedral capsid of all members of the genus Enterovirus. ${ }^{20}$ The original assembly of these four viral proteins forms structural specificities which will serve as cellular binding site: a starshaped dome on the icosahedral 5-fold axis from five VP1 units and a depression surrounding the dome forming a "canyon". ${ }^{21,22,23}$ The majority of RV-A and RV-B binds to ICAM-1, one of the members of the immunoglobulin superfamily, through the "canyon" 24 but the pentameric dome of the minor group (10\% of all RV-A and RV-B) has an affinity for the low-density lipoprotein receptor (LDL-R). ${ }^{25}$ Furthermore, it was recently reported that RV-C15 uses cadherin-related family member 3 (CDHR3) as its cellular receptor. ${ }^{26,27}$ Viruses of the Enterovirus genus, and especially RV-A and RV-B, are characterized by the presence of a hydrophobic cavity under the floor of the canyon. In many RVs, this cavity contains a small lipid molecule of cellular origin, called "pocket factor". ${ }^{28}$ This molecule stabilizes the viral capsid and takes part in the capsid uncoating process during viral entry.

The high genetic and antigenic variability across RVs hampers the development of vaccines and prompts researchers to develop antiviral compounds instead, by targeting conserved proteins like the viral protease $3 \mathrm{C}$ (rupintrivir), ${ }^{29,30}$ or a conserved process like viral entry (capsid 
binders). In particular, capsid binders target the hydrophobic pocket and block virus uncoating and/or attachment. ${ }^{31,32,33,34,35}$ Despite forty years of extensive antiviral research, no antiviral drug has been approved yet for the treatment of rhinovirus infections. The best studied and now reference capsid binder is pleconaril (WIN 63843, 1), ${ }^{36}$ developed by Schering-Plough, for which clinical development for the treatment of rhinovirus infections was halted due to the poor in vivo activity and the rapid selection of drug-resistant variants. Two capsid binders are now in (pre)-clinical phase of development: vapendavir (BTA-798, 2) (Aviragen Therapeutics ${ }^{\circledR}$, clinical trials phase IIb, NCT01175226) (Figure 1) and AZN001 (AstraZeneca, pre-clinical trials), ${ }^{37}$ emphasising that research on this class of inhibitors is far from being abandoned.

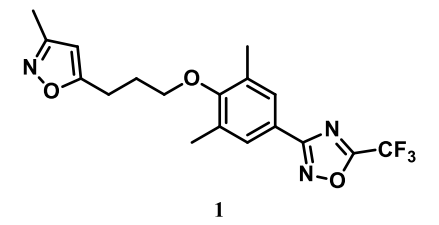

pleconaril (WIN 63843)
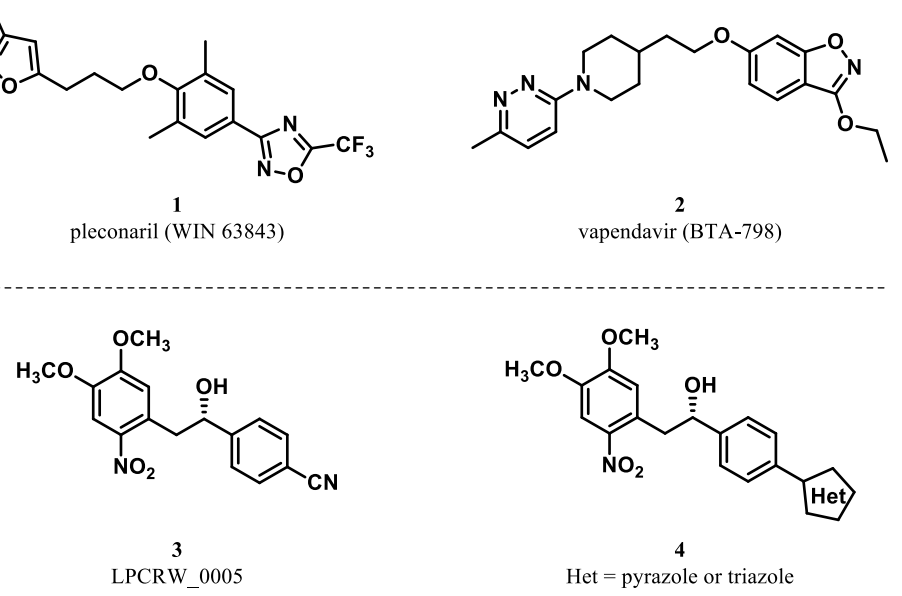

Figure 1. Structure of known capsid binders $\mathbf{1}$ and $\mathbf{2}$ against RVs and our chiral derivatives $\mathbf{3}$ and 4.

Since 2014, we have been developing a new chiral scaffold with a promising antirhinoviral profile against RV-B. The hit 3 (LPCRW_0005) revealed the same antiviral profile and the same binding pocket as pleconaril $1 .^{38,39}$ Extensive pharmacomodulations were necessary to extend the scaffold to fill the residual electron densities observed on the "pore" side and "toe- 
end" side within this hydrophobic pocket. ${ }^{40}$ We discovered new hits, compounds 4 , substituted with pyrazole or triazole moieties, with a potent antiviral activity against RV-B14 (Figure 2 ). ${ }^{41}$

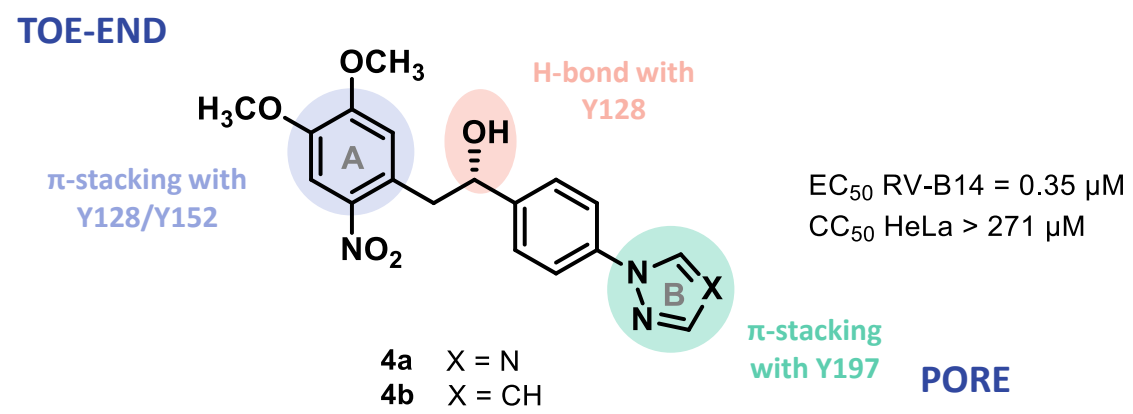

Figure 2. Hits 4 from "pore" side pharmacomodulations: antiviral activity against RV-B14 and essential ligand/protein interactions.

Here, we carried out new heterocyclic pharmacomodulations to lengthen our scaffold on the closed side of the VP1 pocket. This effort led us to identify two analogues similar to 1. Their broad-spectrum activity (RV-A and RV-B) as well as their antiviral mechanism of action have been explored. Moreover, the presence of a nitro group on the cycle A led us to evaluate their in vitro genotoxicity using a micronucleus test. In addition, we have assessed the in vitro resistance emergence against RV-B14 in comparison with 1. Evaluations of the new SARs have also been performed based on in silico molecular docking.

\section{RESULTS}

\section{Synthesis of the heterocyclic antirhinoviral library.}

The synthetic routes for all derivatives studied in this research program are described in Scheme 1. The 2-nitrobenzyl chloride cores 6 were prepared by means of a reduction of carboxylic acid with a stabilized $\mathrm{BH}_{3}$. THF solution. Then, a chlorination with $\mathrm{SOCl}_{2}$ produced 6a-6d. 
The hetero-functionalization on the "pore" side was carried out using an organic electron donor named TDAE (Tetrakis(DimethylAmino)Ethylene). This agent generates a carbanion from benzyl chloride by two sequential single-electron transfer (SET) ${ }^{42}$ A nucleophilic addition on the $\mathrm{C}=\mathrm{O}$ bond of aldehyde derivatives allows then to form the chiral secondary alcohol linker (Scheme 1, route c). So, pyrazole and triazolic derivatives $9 \mathbf{c}-9 \mathbf{f}$ were obtained from commercial reagents (4-(1H-pyrazol-1-yl)benzaldehyde and 4-(1H-1,2,4-triazol-1-yl)benzaldehyde) and 6a6c. For pyridinic analogues, we prepared upstream the aldehyde $\mathbf{8}$ from a Suzuki-Miyaura crosscoupling reaction (Scheme 1, route d) and a TDAE strategy led us to compounds $9 \mathbf{a}$ and $\mathbf{9 b}$.

Finally, the brominated compounds $\mathbf{9 b}, \mathbf{9 c}$ and $\mathbf{9 f}$ are engaged in a last pallado-catalyzed coupling to functionalize the "toe-end" position (Scheme 1, route e). The use of $\mathrm{Pd}\left(\mathrm{PPh}_{3}\right)_{2} \mathrm{Cl}_{2}$ as catalyst allowed us to prepare the pyridinic analogues 10a-10c with yields between 66 and $78 \%$. The last compounds bearing a pyrazole or a triazole $(\mathbf{1 0 d}-\mathbf{1 0 j})$ were prepared with the high reactive catalyst $\mathrm{Pd}(\mathrm{dppf}) \mathrm{Cl}_{2}$ leading to yields up to $96 \%$. 
Scheme 1. General procedure for the synthesis of the heterocyclic antirhinoviral library ${ }^{\mathrm{a}}$

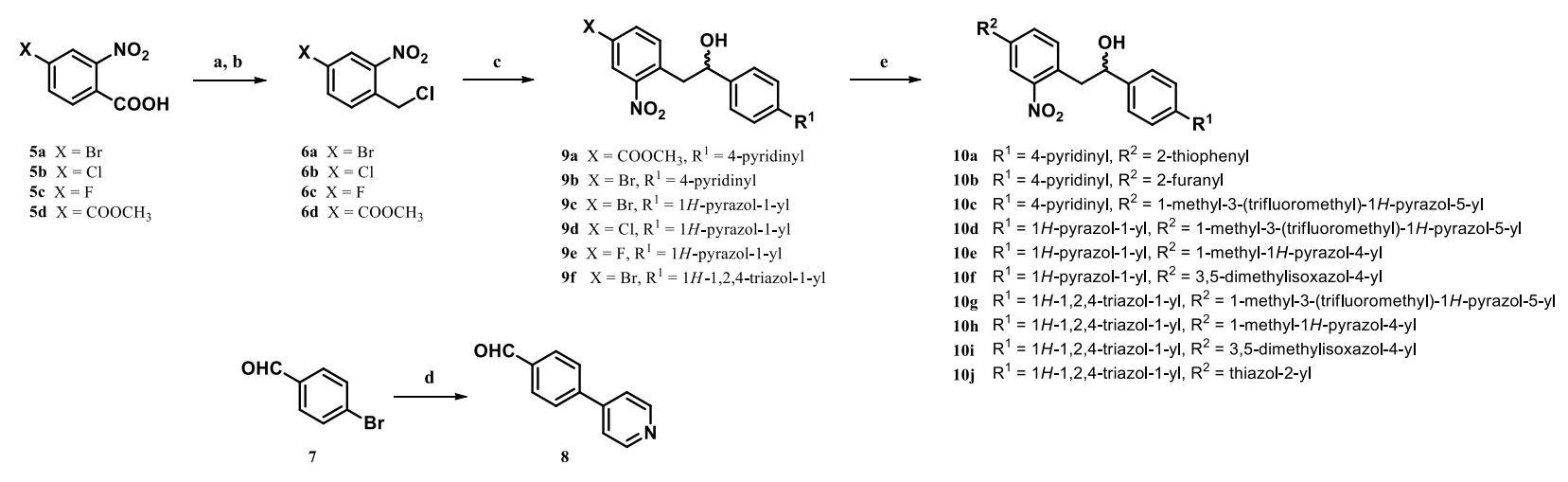

\begin{abstract}
a Reagents and conditions: (a) $\mathrm{BH}_{3}$.THF, THF, RT, 3 days; (b) $\mathrm{SOCl}_{2}, \mathrm{Et}_{3} \mathrm{~N}, \mathrm{CH}_{2} \mathrm{Cl}_{2}, \mathrm{RT}, 12 \mathrm{~h}$, $79-92 \% \quad$ (2 steps); (c) 8, 4-(1H-pyrazol-1-yl)benzaldehyde or 4-(1H-1,2,4-triazol-1yl)benzaldehyde, TDAE, DMF, 1) -20 $\left.{ }^{\circ} \mathrm{C}, 1 \mathrm{~h}, 2\right) \mathrm{RT}, 12 \mathrm{~h}, 13-35 \%$; (d) pyridin-4-ylboronic acid, $\mathrm{Pd}\left(\mathrm{PPh}_{3}\right)_{4}, \mathrm{~K}_{2} \mathrm{CO}_{3}$, DMF/Water, $\mathrm{MW}\left(130{ }^{\circ} \mathrm{C}\right.$ ), $30 \mathrm{~min}, 85 \%$; (e) boronic acid derivative, $\mathrm{Pd}\left(\mathrm{PPh}_{3}\right)_{2} \mathrm{Cl}_{2}, \mathrm{~K}_{2} \mathrm{CO}_{3}$, dioxane, $80{ }^{\circ} \mathrm{C}, 12 \mathrm{~h}, 66-78 \%$ for $10 \mathrm{a}-10 \mathrm{c}$ or boronic acid derivative, $\mathrm{Pd}(\mathrm{dppf}) \mathrm{Cl}_{2}, \mathrm{~K}_{2} \mathrm{CO}_{3}$, dioxane/water, $80{ }^{\circ} \mathrm{C}, 12 \mathrm{~h}, 54-96 \%$ for $\mathbf{1 0 d}-\mathbf{1 0 j}$.
\end{abstract}

\title{
Identification of antirhinoviral compounds by CPE reduction assays.
}

The newly synthesized series of compounds have been evaluated for in vitro antiviral activity against RV-B14 in a cell-based CPE reduction assay on HeLa Rh cells. Antiviral activity is expressed as the concentration at which $50 \%$ of virus-induced $\mathrm{CPE}$ was inhibited ( $\left.\mathrm{EC}_{50}\right)$. Compound cytotoxicity $\left(\mathrm{CC}_{50}\right)$ was assessed in parallel in compound-treated, uninfected cells. Pleconaril 1 was used as a reference capsid binder. Compounds were classified according to the moieties inserted on the "pore" side: 4-pyridinyle, $1 H$-pyrazol-1-yl, or 1H-triazol-1-yl. From there, the antirhinoviral properties of (aza)-heterocycles as well as halogens (chlorine, bromine, and fluor) were studied.

We first assessed the antiviral activity of the pyridinic analogues 9a, 9b, and 10a-10c but we could not detect an improvement of $\mathrm{EC}_{50}$ compared to the hits 4 (Table 1). In contrast, compounds bearing a pyrazole or a triazole (9c-9f and $\mathbf{1 0 d - 1 0 j}$ ) on the "pore" side showed a 
more potent antiviral activity against RV-B14 compared to 4 , especially those substituted with a 1-methyl-1H-pyrazol-4-yl towards the "toe-end" side (10e and 10h), with EC 50 values of $0.2 \mu \mathrm{M}$ and a SI $>1235 \mu \mathrm{M}$. Moreover, we found that the substitution of a trifluoromethyl group on the pyrazole moiety $(\mathbf{1 0 d}$ and $\mathbf{1 0 g})$ increased the $\mathrm{EC}_{50}$ values of the compounds and significantly affected the cytotoxicity of the respective compounds $\left(\mathrm{CC}_{50}=14-21 \mu \mathrm{M}\right)$, thereby decreasing their selectivity index. The dimethylisoxazol moieties (10f and 10i) induced a complete loss of antiviral activity against RV-B14. These observations underline the significance of steric hindrance on the "toe-end" side.

In addition, brominated analogues 9c and 9f showed a similar antiviral activity but a less desirable SI due to a considerable anti-metabolic activity $\left(\mathrm{CC}_{50}<39 \mu \mathrm{M}\right)$. To overcome this toxicity, the chlorinated (9d) and fluorinated (9e) compounds have been evaluated. By providing fluorine and chlorine, bioisostere of bromine, the cytotoxic effects on HeLa cells were significantly improved $\left(\mathrm{CC}_{50}>100\right)$.

Altogether, these data indicate that the addition of a methylpyrazole or chlorine can improve the antiviral activity with negligible cell toxicity, thus improving the SI. The two most promising hits (10e and 10h) displayed the required characteristics for the further studies. 
Table 1. In vitro biological activity of racemic compounds against RV-B14. ${ }^{\text {a }}$

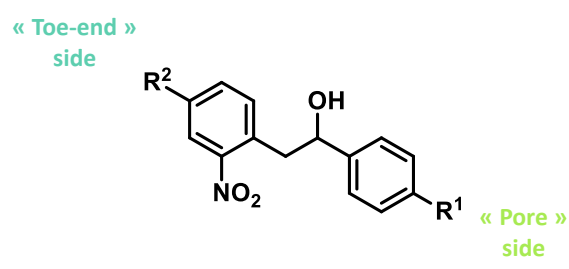

\begin{tabular}{|c|c|c|c|c|c|c|}
\hline Entry & (rac)-Compd & $\mathbf{R}^{1}$ & $\mathbf{R}^{2}$ & $\begin{array}{c}\text { EC50 RV-B14 }(\mu \mathrm{M})^{\mathrm{b}} \\
\end{array}$ & $\begin{array}{c}C_{50} \mathrm{HeLa} \\
(\mu \mathrm{M})^{\mathrm{c}}\end{array}$ & $\mathbf{S I}^{\mathrm{d}}$ \\
\hline 1 & $9 a$ & 4-pyridinyl & $\mathrm{COOCH}_{3}$ & $6.4 \pm 1.1$ & $>264$ & $>41$ \\
\hline 2 & $9 b$ & 4-pyridinyl & $\mathrm{Br}$ & $0.59 \pm 0.01$ & $>250$ & $>424$ \\
\hline 3 & $10 \mathrm{a}$ & 4-pyridinyl & & $1.3 \pm 0.5$ & $>248$ & $>191$ \\
\hline 4 & $10 \mathrm{~b}$ & 4-pyridinyl & & $1.2 \pm 0.2$ & $>86$ & $>72$ \\
\hline 5 & $10 \mathrm{c}$ & 4-pyridinyl & & $1.0 \pm 0.3$ & $>100$ & $>100$ \\
\hline 6 & $9 c$ & $1 H$-pyrazol-1-yl & $\mathrm{Br}$ & $0.25 \pm 0.06$ & $22.5 \pm 0.7$ & 90 \\
\hline 7 & 9d & $1 H$-pyrazol-1-yl & $\mathrm{Cl}$ & $0.128 \pm 0.004$ & $>100$ & $>781$ \\
\hline 8 & $9 e$ & $1 H$-pyrazol-1-yl & $\mathrm{F}$ & $8.7 \pm 0.1$ & $>100$ & $>12$ \\
\hline 9 & 10d & $1 H$-pyrazol-1-yl & & $0.5 \pm 0.3$ & $14 \pm 12$ & 29.4 \\
\hline 10 & $10 \mathrm{e}$ & $1 H$-pyrazol-1-yl & & $0.2 \pm 0.1$ & $>247$ & $>1235$ \\
\hline 11 & $10 f$ & $1 H$-pyrazol-1-yl & & $>247$ & $14 \pm 3$ & - \\
\hline 12 & 9f & $1 H-1,2,4$-triazol-1-yl & $\mathrm{Br}$ & $0.25 \pm 0.07$ & $39 \pm 1$ & 156 \\
\hline 13 & $10 \mathrm{~g}$ & 1H-1,2,4-triazol-1-yl & & $0.4 \pm 0.2$ & $21 \pm 4$ & 52.5 \\
\hline 14 & $10 \mathrm{~h}$ & $1 H-1,2,4$-triazol-1-yl & & $0.18 \pm 0.05$ & $>256$ & $>1422$ \\
\hline 15 & $10 \mathrm{i}$ & $1 H$-1,2,4-triazol-1-yl & & $>247$ & $>256$ & - \\
\hline 16 & $\mathbf{1 0 j}$ & 1H-1,2,4-triazol-1-yl & $s \mathbb{N}^{\mathbb{N}}$ & $0.4 \pm 0.2$ & $44 \pm 14$ & 110 \\
\hline 17 & 1 & pleconaril & & $0.03 \pm 0.02$ & $>131$ & $>4039$ \\
\hline
\end{tabular}

${ }^{\mathrm{a}}$ All values are expressed as median \pm Med. Abs. Dev. ${ }^{\mathrm{b}} \mathrm{EC}_{50}=50 \%$ effective concentration (concentration at which $50 \%$ inhibition of virus-induced cell death is observed). ${ }^{\mathrm{c}} \mathrm{CC}_{50}=50 \%$ cytotoxic concentration (concentration at which 50\% adverse effect is observed on host cell viability). ${ }^{\mathrm{d}} \mathrm{SI}=$ selectivity index for $\mathrm{RV}-\mathrm{B} 14, \mathrm{SI}=\mathrm{CC}_{50} / \mathrm{EC}_{50}$. (rac) $=$ racemic. 


\section{Absolute configuration influence 10e and 10h pharmacological activities.}

We previously observed that enantioseparation significantly improves the activity of this class of compounds. ${ }^{41}$ Therefore, we proceeded to the separation and characterization of the enantiomers for compounds $\mathbf{1 0 e}$ and $\mathbf{1 0 h}$, and we tested the antiviral activity of the separated enantiomers against RV-B14 in a cell-based CPE reduction assay.

The two enantiomers were correctly separated according to the same methodology previously described. ${ }^{41}$ To determine their absolute configuration, we used again a Mosher's protocol by using the enantiomers $\mathbf{1 0 h}$ followed by circular dichroisms to know the stereochemistry of the enantiopure compounds 10e. This detail methodology is described in the supporting information.

Similarly to the previous series of enantioseparated compounds, we appreciated an increased antiviral activity and selectivity index for the $(S)$-enantiomers (Table 2). The fold increase of $\mathrm{EC}_{50}$ of these enantiopure compounds compared to the racemic mixture was more pronounced than that observed in the previous series. ${ }^{41}$ Despite the retained antiviral activity of the $(R)-\mathbf{1 0 e}$ enantiomer, the $(S)$-configuration of compound 10e showed a gain in activity of 5.7 fold, whereas (S)-10h was 3 fold more active than the racemic counterpart. For the enantioseparatedcompounds, an antiviral activity similar to or higher than that of $\mathbf{1}$ was reached. In summary, we identified two new hit compounds equally active as pleconaril 1, in the context of in vitro RVB14 infection. Furthermore, we could further demonstrate that enantioseparation significantly improves the antiviral activity and selectivity index of this class of compounds. 
Table 2. In vitro biological activity of enantiopure compounds against RV-B14. ${ }^{\mathrm{a}}$

\begin{tabular}{ccccc}
\hline Entry & Compd & $\begin{array}{c}\text { EC } 5 \mathbf{R V}-\mathbf{R} 14 \\
(\boldsymbol{\mu M})^{\mathrm{b}}\end{array}$ & $\begin{array}{c}\mathbf{C C}_{\mathbf{5 0}} \mathbf{H e L a} \\
(\boldsymbol{\mu} \mathbf{M})^{\mathrm{c}}\end{array}$ & $\mathbf{S I}^{\mathrm{d}}$ \\
\hline 1 & $\mathbf{1 0 e ^ { * }}$ & $0.2 \pm 0.1$ & $>1000$ & $>5000$ \\
2 & $(S)-\mathbf{1 0 e}$ & $0.035 \pm 0.006$ & $>342$ & $>9771$ \\
3 & $(R)-\mathbf{1 0 e}$ & $2.5 \pm 0.9$ & $>342$ & $>136$ \\
\hline 4 & $\mathbf{1 0 h}$ & $0.18 \pm 0.05$ & $699 \pm 63$ & 3883 \\
5 & $(S)-\mathbf{1 0 h}$ & $0.06 \pm 0.03$ & $>342$ & $>5700$ \\
6 & $(R)-\mathbf{1 0 h}$ & $>128$ & $>342$ & - \\
\hline 7 & $\mathbf{1}$ & $0.03 \pm 0.02$ & $>131$ & $>4039$ \\
\hline
\end{tabular}

${ }^{\mathrm{a}}$ All values are expressed as median \pm Med. Abs. Dev. ${ }^{\mathrm{b}} \mathrm{EC}_{50}=50 \%$ effective concentration (concentration at which $50 \%$ inhibition of virus-induced cell death is observed). ${ }^{\mathrm{c}} \mathrm{CC}_{50}=50 \%$ cytotoxic concentration (concentration at which 50\% adverse effect is observed on host cell viability). ${ }^{\mathrm{d}} \mathrm{SI}=$ selectivity index for $\mathrm{RV}-\mathrm{B} 14, \mathrm{SI}=\mathrm{CC}_{50} / \mathrm{EC}_{50} . *$ Racemic compound.

\section{Pan-RV activities of $10 \mathrm{e}$ and $10 \mathrm{~h}$.}

The antiviral activity of the most promising compounds of the series, compounds $\mathbf{1 0 e}$ and $\mathbf{1 0 h}$, and their enantioseparated counterparts was evaluated against a representative panel of rhinoviruses belonging to type A and type B: RV-A02, RV-A08, RV-A28, RV-A85, and RVA89 (type A) and RV-B42 and RV-B70 (type B).

All the compounds resulted to be active against RV-group $\mathrm{B}$ in a similar range, with the exception of RV-B42 type, which is known to be naturally resistant to pleconaril-like capsid binders. ${ }^{46}$ Interestingly, for the first time, we could detect an antiviral activity of this class of compounds against A-group, in particular in the context of RV-A89 infection. Remarkably, for the only type A-virus sensitive to compounds $10 \mathbf{e}$ and $\mathbf{1 0 h}$, the $(R)$-configuration was more active than the $(S)$-configuration. This switch in enantiomer activity could reflect specific properties of the pocket. 
Table 3. Evaluation of pan-RV activities of the enantiomers of $10 \mathbf{e}$ and $10 \mathbf{h} .^{\mathrm{a}}$

\begin{tabular}{|c|c|c|c|c|c|c|}
\hline \multicolumn{2}{|c|}{ Types } & $\begin{array}{l}\mathbf{E C}_{50} 1 \\
(\mu \mathrm{M})^{\mathrm{b}}\end{array}$ & $\begin{array}{c}\mathrm{EC}_{50}(S)-10 \mathrm{e} \\
(\mu \mathrm{M})^{\mathrm{b}}\end{array}$ & $\begin{array}{c}\mathrm{EC}_{50}(R)-10 \mathrm{e} \\
(\mu \mathrm{M})^{\mathrm{b}}\end{array}$ & $\begin{array}{c}\mathrm{EC}_{50}(S)-10 \mathrm{~h} \\
(\mu \mathrm{M})^{\mathrm{b}}\end{array}$ & $\begin{array}{c}\mathrm{EC}_{50}(R)-10 \mathrm{~h} \\
(\mu \mathrm{M})^{\mathrm{b}}\end{array}$ \\
\hline \multirow[t]{5}{*}{ RV-A } & RV-A02 & $0.015 \pm 0.002$ & $>128$ & $>128$ & $>128$ & $>128$ \\
\hline & RV-A08 & $0.49 \pm 0.09$ & $>128$ & $>128$ & $>128$ & $>128$ \\
\hline & RV-A28 & $0.015 \pm 0.008$ & $>128$ & $>128$ & $>128$ & $>128$ \\
\hline & RV-A85 & $0.011 \pm 0.002$ & $>128$ & $>128$ & $>128$ & $>128$ \\
\hline & RV-A89 & $\begin{array}{c}0.0040 \pm \\
0.0001\end{array}$ & $2.4 \pm 0.5$ & $0.190 \pm 0.001$ & $>128$ & $1.5 \pm 0.4$ \\
\hline \multirow[t]{3}{*}{ RV-B } & RV-B14 & $0.03 \pm 0.02$ & $0.035 \pm 0.006$ & $2.5 \pm 0.9$ & $0.06 \pm 0.03$ & $>128$ \\
\hline & RV-B42 & $>128$ & $>128$ & $>128$ & $>128$ & $>128$ \\
\hline & RV-B70 & $0.167 \pm 0.007$ & $0.017 \pm 0.006$ & $>128$ & $0.05 \pm 0.03$ & $>20$ \\
\hline
\end{tabular}

${ }^{\mathrm{a}}$ All values are expressed as median \pm Med. Abs. Dev. ${ }^{\mathrm{b}} \mathrm{EC}_{50}=50 \%$ effective concentration (concentration at which $50 \%$ inhibition of virus-induced cell death is observed).

10e and $10 \mathrm{~h}$ act as early stage inhibitors of rhinovirus replication.

To confirm the mode of action of the newly synthetized analogues, a time of addition experiment was performed. Compounds $10 \mathrm{e}$ and $\mathbf{1 0 h}$ and the most active enantioseparated counterparts were added at selected time points before, during, and after infection. Viral replication was then quantified 8 hours after infection by RT-qPCR on intracellular viral RNA. We observed that both the racemic mixtures of $\mathbf{1 0 e}$ and $\mathbf{1 0 h}$ and the purified enantiomers $(S)-\mathbf{1 0 e}$ and (S)-10h interfered with RV-B14 replication at an early stage. The compounds could prevent virus replication only when added 2 hours prior or at the time of infection, which was reflected in a decreased intracellular viral RNA load at 8 hours post infection (Figure 3). The inhibitory effect of the molecules was lost when added 2 hours after infection (no reduction in viral RNA load compared to the virus control (VC)) indicating that the compounds act at an early stage of rhinovirus replication, similarly to 1 and the initial hit 3 (LPCRW_0005). ${ }^{39}$ These observations suggest that the performed pharmacomodulations did not alter the mechanism of action of this series of compounds. 


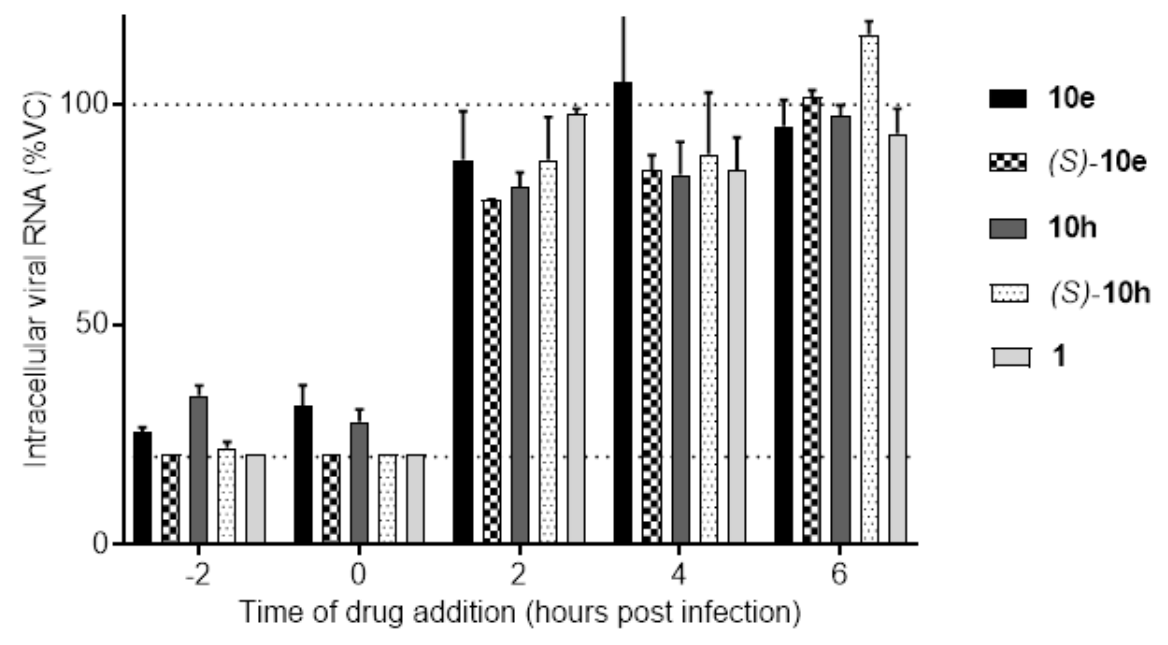

Figure 3. Similar to 1, compounds $10 \mathrm{e}$ and $\mathbf{1 0 h}$ and their active enantiomers interfere with RVB14 replication at an early stage.

Drug-resistance development is delayed in presence of compounds $10 \mathrm{e}$ and $10 \mathrm{~h}$ as compared with pleconaril 1.

The rapid development of resistance against capsid binders is a major burden both in vitro and in vivo, as demonstrated by several clinical trials. To evaluate the dynamics of resistance emergence, RV-B14 was passaged in the presence of $\mathbf{1 0 e}, \mathbf{1 0 h}$ and $\mathbf{1}$ at their in vitro $\mathrm{EC}_{50}$, $2 \mathrm{xEC}_{50}$ and $4 \mathrm{xEC}_{50}$ (Table 4). In the sub-optimal concentration (in vitro $\mathrm{EC}_{50}$ ), the three compounds developed resistance by passage 3 , with 10e-treated cultures being less prone to develop resistance by passage 4 (only $50 \%$ of infected-treated cultures showed viral-induced $\mathrm{CPE})$. However, at the higher concentration of $2 \mathrm{xEC}_{50}$ and $4 \mathrm{xEC}_{50}$, which correspond to an efficacious antiviral treatment, resistance development was more rapid in 1-treated than in 10eand 10h-treated cultures. Although it is difficult to ultimately conclude on in vitro evolutionary experiments, these data may suggest that RV-B14 is less prone to develop resistance in presence of compound 10e or $10 \mathrm{~h}$ compared to 1. 
Table 4. RV-B14 induced CPE at passage 1-4 (P1-4) in the presence of compounds $\mathbf{1 0 e}$, 10h, or 1.

\begin{tabular}{|c|c|c|c|c|c|}
\hline Compd & $\mathrm{xEC}_{50}$ & $\mathbf{P 1}^{\mathbf{a}}$ & $\mathbf{P} 2^{\mathbf{a}}$ & $\mathbf{P 3}^{\mathbf{a}}$ & $\mathbf{P 4}^{\mathbf{a}}$ \\
\hline \multirow{3}{*}{$10 \mathrm{e}$} & 4 & $0 \%$ & $0 \%$ & $0 \%$ & $0 \%$ \\
\hline & 2 & $0 \%$ & $0 \%$ & $0 \%$ & $50 \%$ \\
\hline & 1 & $0 \%$ & $0 \%$ & $50 \%$ & $50 \%$ \\
\hline \multirow{3}{*}{$10 \mathrm{~h}$} & 4 & $0 \%$ & $0 \%$ & $0 \%$ & $0 \%$ \\
\hline & 2 & $0 \%$ & $0 \%$ & $25 \%$ & $50 \%$ \\
\hline & 1 & $0 \%$ & $50 \%$ & $75 \%$ & $100 \%$ \\
\hline \multirow{3}{*}{1} & 4 & $0 \%$ & $0 \%$ & $25 \%$ & $25 \%$ \\
\hline & 2 & $0 \%$ & $0 \%$ & $100 \%$ & $100 \%$ \\
\hline & 1 & $0 \%$ & $100 \%$ & $100 \%$ & $100 \%$ \\
\hline $\mathrm{VC}$ & & $100 \%$ & $100 \%$ & $100 \%$ & $100 \%$ \\
\hline
\end{tabular}

aPercentage of wells showing full CPE $(n=4)$. VC: virus control.

Next, in order to correlate the resistant phenotype to eventual drug-resistant virus variants, the VP1 genomic region from the cultures treated with compound $10 \mathbf{e}$ and $\mathbf{1 0 h}$ at passage 4 was analyzed by sequencing. Virus harvested from cultures that proofed to be equally sensitive to the compound after four passages and that did not show any sign of viral-induced CPE, did not show any mutations except for four (out of 14) cultures that carried either the amino acid A150V or V191E. Both mutations have been associated with in vitro resistance to $1 .{ }^{43}$ On the other hand, the virus harvested from drug-resistant cultures carried one of the mutations A150V, C199W, or N105S. As mentioned before, the A150V but also the position C199 (C199Y variant) was previously described for in vitro resistance to $1 .{ }^{44}$ The N105S substitution is a novel variant associated to $\mathbf{1 0 h}$ resistance. 
Table 5. Mutations detected in the VP1 gene of RV-B14 cultures 1-4 (C1-C4) after 4 passages in the presence of compounds $\mathbf{1 0 e}$ or $\mathbf{1 0 h}$.

\begin{tabular}{cccccc}
\hline \multirow{2}{*}{ Compd } & xEC $_{50}$ & C1 & C2 & C3 & C4 \\
\hline \multirow{2}{*}{$\mathbf{1 0 e}$} & $\mathbf{4}$ & $\mathrm{A} 150 \mathrm{~V}$ & $\mathrm{~A} 150 \mathrm{~V}$ & - & - \\
& $\mathbf{2}$ & $\mathrm{A} 150 \mathrm{~V}$ & $\mathrm{~A} 150 \mathrm{~V}$ & $\mathrm{~V} 191 \mathrm{E}$ & - \\
& $\mathbf{1}$ & $\mathrm{C} 199 \mathrm{~W}$ & $\mathrm{C} 199 \mathrm{~W}$ & - & - \\
\hdashline & $\mathbf{4}$ & $\mathrm{A} 150 \mathrm{~V}$ & - & - & - \\
$\mathbf{1 0 h}$ & $\mathbf{2}$ & $\mathrm{N} 105 \mathrm{~S}$ & $\mathrm{~N} 105 \mathrm{~S}$ & - & - \\
& $\mathbf{1}$ & $\mathrm{C} 199 \mathrm{~W}$ & $\mathrm{C} 199 \mathrm{~W}$ & $\mathrm{C} 199 \mathrm{~W}$ & $\mathrm{C} 199 \mathrm{~W}$ \\
\hline
\end{tabular}

Green: no CPE. Red: full CPE.

\section{In vitro genotoxicity study.}

The presence of a nitro group led us to evaluate the potential clastogenic and/or aneugenic activities of the most active enantiomers $(S)$-10e and $(S)$-10h. Indeed, the nitroaromatics can be reduced in vivo to form several reactive intermediates (nitro radical, nitroso, nitroxyl radical, or aromatic N-oxide). In this research, their genotoxic effects were evaluated using an in vitro micronucleus clastogenicity study. ${ }^{45}$ This essay detects compounds that damage chromosomes or interfere with the cell division apparatus, to produce abnormal DNA fragments. It is currently a prerequisite for future drug development, especially in the framework of research on nitro compounds.

The test is conducted by incubating $\mathrm{CHO}$ cells in culture with the test compounds at increasing concentrations $(1 \mu \mathrm{M}$ to $100 \mu \mathrm{M})$, with and without metabolic activation. After exposure, the cells are cultured for a period of time allowing the formation of micronuclei in interphase daughter cells in the presence of a blocking agent of cytokinesis (cytochalasin B). The harvested cells in interphase are subjected to specific staining and analysis for the presence of micronuclei.

All results are presented in Tables A and B (Supporting information). No significant increase in micronucleated cell rates was observed for all the non-cytotoxic concentrations, in either the 
absence or presence of the metabolizing mixture. These data indicated that the compounds $(S)$ 10e and (S)-10h did not exert cytogenetic effects in CHO cells in culture, and did not produce metabolites with cytogenetic effects. As a conclusion, these capsid binders gave negative results in the in vitro micronucleus assay, indicating that they devoid of clastogenic and/or aneugenic activities in these experimental conditions.

\section{Molecular modelling.}

The reported derivatives were studied by docking experiments to gain insight into the compounds binding mode. The binding pocket was fixed at the capsid site and the computation were carried out by a previously reported procedure. ${ }^{40}$ The analyses of the Plants proposed binding poses showed that the compounds shared a consistent binding mode, superimposable with the one of the reference compounds $\mathbf{3}$ and $\mathbf{4 a}$ (Figure 5).
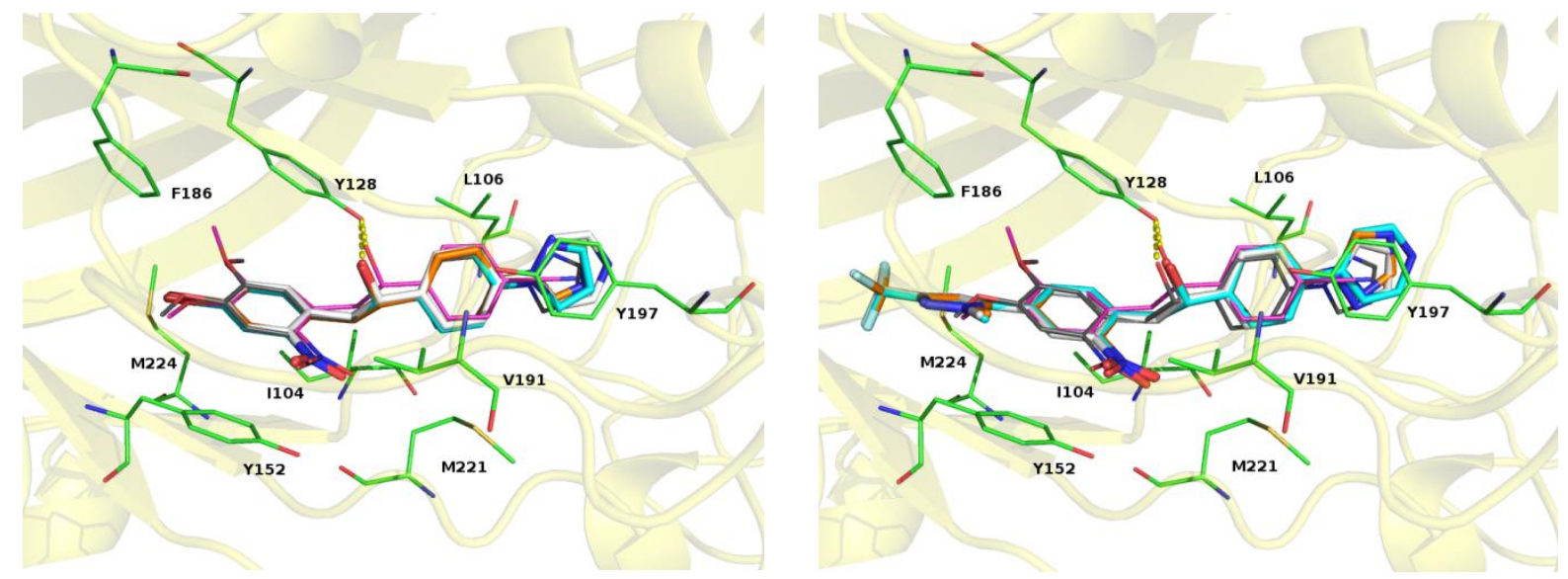

Figure 5. Plants proposed binding mode for compounds (left panel) 9b (white), 9c (orange), and 9f (cyan); and (right panel) 10c (cyan), 10d (white), and 10g (orange). References compounds, 3 magenta, and 4a grey, were also reported as lines. Residues involved in contacts were depicted as green lines. VP1 protein is reported as yellow cartoon. H-bonds are showed as yellow dot lines. 
The binding mode analyses led us to highlight some key interactions: (a) the nitro-phenyl moiety had $\pi-\pi$ staking with Y152, (b) the linker oxygen atom formed an H-bond with Y128 side chain, and (c) the unsubstituted phenyl ring had hydrophobic interactions with L106, V191 and M221 side chains. The pore side substituents (pyridine, pyrazole, and triazole) were involved in $\pi-\pi$ staking contact with Y197. The toe-end substituents had to be divided in two groups: the aromatic groups formed staking contact with F186 (Figure 5, right panel); whereas the halogen atoms established steric rather than electrostatic interactions at the hydrophobic pocket mainly formed by Y152, F186, and M224 (Figure 5, left panel). More in detail, by comparing the compounds 10d, 10e, and 10f, we observed that the dimethylisoxazole moiety led to an unrelated binding mode, while the $\mathrm{CF}_{3}(\mathbf{1 0 d})$ and the $\mathrm{CH}_{3}$ (10e) groups were superimposable and had hydrophobic contacts with I130, A150, and V176 (Figure D, Supporting information).

We also studied the binding modes of the 10e and 10h enantiomers. The docking poses showed a main difference between the $(R)$ and $(S)$ couples. The $(S)$-enantiomers were in the right geometry to form an H-bond between the chiral oxygen alcohol atom and the Y128 side chain; on the contrary, for $(R)$-enantiomers the alcohol group pointed toward the hydrophobic residue V191 destabilizing the binding (Figure 6). This was in accordance with the biological data and consistent with the already reported docking poses. ${ }^{41}$ 


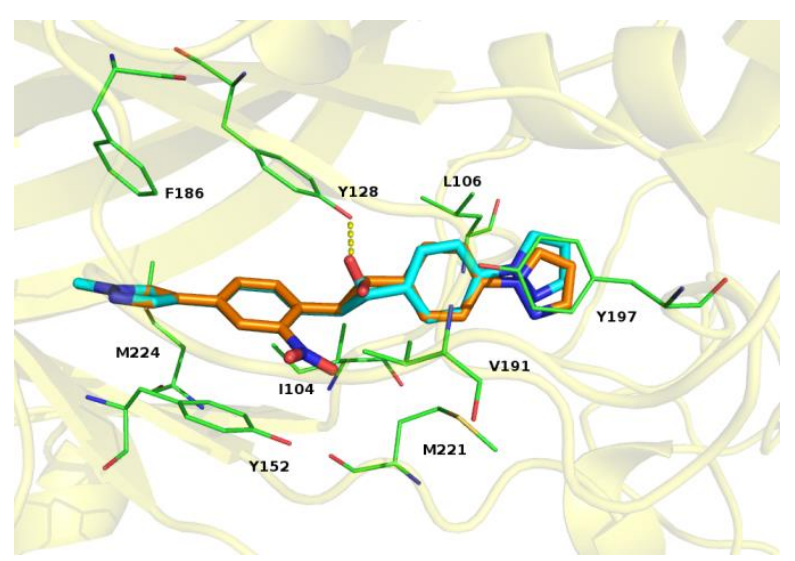

Figure 6. Plants proposed binding mode for derivatives (R)-10e (orange) and (S)-10e (cyan). Residues involved in contacts were depicted as green lines. VP1 protein is reported as yellow cartoon. H-bond is showed as yellow dot line.

The capsid binder compounds integrate into a highly conserved pocket mainly formed by VP1. ${ }^{46}$ The serotypes VP1 primary sequence conservation was studied in order to clarify the broad range susceptibility of the $\mathbf{1 0 e}$ and $\mathbf{1 0 h}$ compounds. The analyses were focused on the residues directly involved in interactions with studied compounds.

For the RV-B studied isotypes (Table 4), the comparison between RV-B14 and RV-B70 isotypes highlighted that only the M224 changed to isoleucine. This residue had a role in the stabilization of studied compounds doing contacts with the toe-end substituents. Nevertheless, this residue change did not affect the contact and the binding mode (data not shown). Actually, the more hydrophobic nature of the isoleucine might strengthen the interaction with the pyrazole ring. The comparison between the RV-B14 and RV-B42 highlighted two residues change: Y152 to Phe and V191 to Leu. The pattern F152/L191 was already described as "diagnostic" for resistance to capsid binder. ${ }^{46,}{ }^{46}$ In particular, the bulkier leucine instead of valine might have a detrimental steric effect in the compounds binding. This hypothesis was confirmed by docking 
studies at the homology model for the RV-B42 VP1. The docking experiments for 10e and 10h led to an unrelated binding mode (data not shown).

Table 4. VP1 alignment of the amino acids of RV-B types in the binding pocket.

\begin{tabular}{c|ccccccccccccccccccccccccc}
\multicolumn{11}{c}{ Amino acid position } \\
RV-B & 102 & 104 & 106 & 116 & 124 & 126 & 128 & 150 & 151 & 152 & 174 & 175 & 176 & 186 & 188 & 191 & 197 & 198 & 219 & 221 & 224 & 245 \\
\hline 14 & W & I & L & L & F & S & Y & A & M & Y & P & S & V & F & V & V & Y & N & N & M & M & H \\
42 & - & - & - & - & - & - & - & - & - & F & - & - & - & - & - & L & - & - & - & - & - & - \\
70 & - & - & - & - & - & - & - & - & - & - & - & - & - & - & - & - & - & - & - & - & I & -
\end{tabular}

We also analysed the VP1 sequence for the RV-A studied isotypes (Table 5). Our aim was to rationalize the important inhibitory activity of $\mathbf{1 0 e}$ and $\mathbf{1 0 h}$ at the A89 isotype. Worthy, the valine 98 was peculiar for A89 isotype, and this residue was in the central part of the canyon. The docking experiments at the RV-A89 VP1 homology model confirmed the role of V98. Indeed, the smaller valine instead of an isoleucine, which featured the other studied isotypes, created a small space filled by the inhibitors nitro group. This binding mode was also featured by: (a) an aromatic contact between the pore side pyrazole and Y190; (b) a hydrophobic interaction between the toe-end pyrazole and F179 and I217; and (c) the nitro-phenyl group formed contact with Y144 and I181. Worthily, the reported binding mode showed only for the (R)-enantiomers an H-bond with the S120 side chain (Figure 7).

Table 5. VP1 alignment of the amino acids of RV-A types in the binding pocket.

Amino acid position

\begin{tabular}{c|cccccccccccccccccccccccccc} 
RV-A & 77 & 96 & 98 & 100 & 118 & 120 & 122 & 124 & 142 & 143 & 144 & 166 & 167 & 168 & 179 & 181 & 184 & 190 & 212 & 214 & 217 & 238 \\
\hline 89 & I & W & V & L & F & S & I & I & F & M & Y & A & S & V & F & I & M & Y & N & M & I & H \\
2 & - & - & I & - & - & - & - & L & Y & - & - & - & - & - & - & L & L & - & - & - & L & - \\
8 & - & - & I & I & - & - & - & - & I & - & - & - & - & - & - & - & S & - & - & - & - & L \\
28 & - & - & I & - & - & - & - & - & - & - & - & - & - & - & - & - & - & - & & - & L & - \\
85 & - & - & I & I & - & - & - & L & Y & - & - & - & - & - & - & - & - & - & - & - & L & -
\end{tabular}




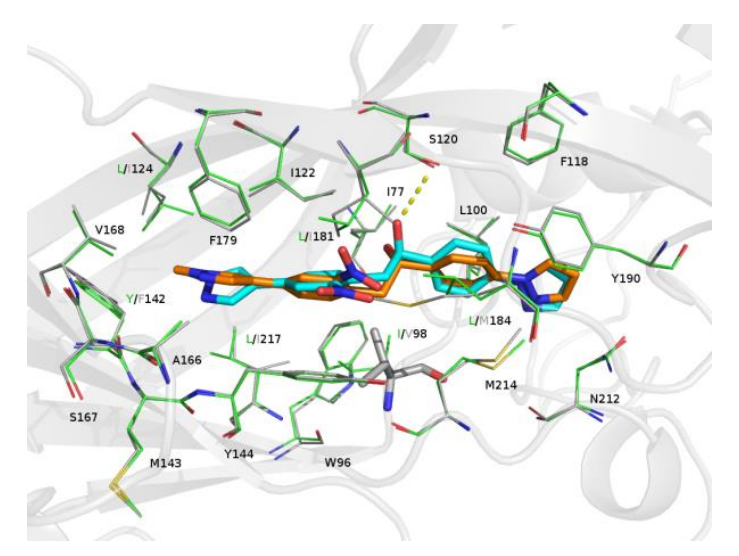

Figure 7. Proposed binding mode for the compounds (R)-10e (cyan) and (S)-10e (orange) at RVA89 isotype. Residues of RV-A2 are reported as green line; residues of RV-A89 are reported as grey lines. The cartoon of A89 isotype is also reported. H-bond is showed as yellow dot line.

The docking studies provided us a general binding mode able to fit the biological activity. Nevertheless, several other factors might be involved in the compounds binding such as: the effect of other changed amino acids, the residues outside the binding pocket and the compounds accessibility to the pocket.

\section{DISCUSSION}

Capsid binders are still considered attractive molecules for the prophylaxis and treatment of rhino/enterovirus infections, as witnessed by the abundancy of studies/clinical trials over the recent years. These molecules target the hydrophobic pocket beneath the floor of the canyon formed by approximately twenty amino acids of VP1. This viral protein is highly variable across rhinoviruses and enteroviruses and so is the composition of the pocket. It is hence a challenge to design molecules that are at the same time strong capsid binders and pan-genotype active. Here, we describe the chemical modulation of a pleconaril-like capsid binder with an equal in vitro antiviral activity as pleconaril $\mathbf{1}$ and an expanding spectrum of activity across rhinoviruses. 
We report, for the first time since we have been working with the compound 4 backbone, an analogue with a comparable in vitro antiviral potency as $\mathbf{1}$. Indeed, following enantioseparation, (S)-10h showed an equal potency in the context of RV-B14 infection and an even higher potency than 1 after RV-B70 infection. In addition, both 10e and 10h new hits exhibited a delayed in vitro resistance development when compared with $\mathbf{1}$. Although the interpretation of in vitro evolutionary experiments is challenging, our data suggest that RV-B14 is less prone to develop resistance in presence of compound $10 \mathrm{e}$ and $10 \mathrm{~h}$ compared to 1 . As resistance development has been a major problem during the clinical development phase of $\mathbf{1}$, our data on this novel class of pleconaril-like compounds are highly encouraging. Moreover, we correlated the resistance phenotype with mutations in VP1. Two of the altered positions (A150 and C199) were previously associated with resistance to $\mathbf{1}$, whereas $\mathrm{N} 105 \mathrm{~S}$ is a newly identified variant specifically associated with compound $\mathbf{1 0 h}$ and/or $10 \mathbf{e}$. These residues lay in close proximity with the residues defining the hydrophobic pocket, suggesting that the environment around the pocket is also crucial for compound-binding.

This study also shed light on the dynamics of interaction of the newly synthetized $\mathrm{x}$-analogues with the binding pocket by means of molecular docking simulations. We could identify the residue V98 in RV-A as a key residue associated with in vitro antiviral activity. In addition, we could explain the different enantiomer preference in the context of RV-B or RV-A89 infection. Only the $(R)$-enantiomer could engage in an H-bond with the pocket residue S120, suggesting that this residue is also crucial for antiviral activity. Altogether these data will guide the synthesis of more potent and broad-spectrum compounds. 


\section{CONCLUSION}

In summary, we identified a novel anti-RV inhibitors series with a promising pharmacological profile. Several compounds displayed sub-micromolar $\mathrm{EC}_{50}$ values against a representative panel RV species. Following our previous work, we undertook this SAR study in order to lengthen our scaffold on the closed side of the hydrophobic pocket, called the "toe-end". With this we have confirmed the interest of hydrophobic interactions with the residues I130, A150, and V176 of "toe-end" side. Several pharmacophores have been identified with in particular a methyl pyrazole inducing numerous hydrophobic interactions within the pocket. Among the novel compounds investigated, the enantiopure compounds $10 \mathrm{e}$ and $\mathbf{1 0 h}$ were found to inhibit replication of RV-A and RV-B species with an $\mathrm{EC}_{50}$ between 0.017 and $0.19 \mu \mathrm{M}$ against RVB14, RV-B70 and RV-A89 respectively, which is comparable to 1. A determination of the absolute configuration by a Mosher protocol validated the importance of the $(S)$-alcohol linker against RV-B14 and RV-B70. Conversely, the (R)-stereocenter of 10e induces activity against RV-A89. The docking study showed that an H-bond with S120 is the key to this activity.

The results of time-of-addition experiments, in which $(S)-\mathbf{1 0 e}$ and $(S)$-10h showed a similar inhibition profile with that of $\mathbf{1}$ against RV-B14, and a resistant development study, implied that $\mathbf{1 0}$ act at the early stage of the viral infection. In addition, a new point mutation N105S on the viral capsid protein was identified. In vitro genotoxicity study also displayed that $\mathbf{1 0}$ have no clastogenic and/or aneugenic activities in $\mathrm{CHO}$ cells despite the nitro group. In conclusion, these complete studies led us to identify two potent antivirals with a broad-spectrum activity against RV-A and RV-B species. In view of the promising pharmacological properties, we thus will explore the pan-EV potential of these new pyrazolic inhibitors. 


\section{EXPERIMENTAL SECTION}

\section{Chemistry.}

General methods. Commercially available reagents and solvents were used without further purification. Reactions were monitored by thin-layer chromatography (plates coated with silica gel $60 \mathrm{~F}_{254}$ from Merck) and by LC-MS analyses with a Thermo Scientific Accela High Speed LC System ${ }^{\circledR}$ coupled with a single quadrupole mass spectrometer Thermo MSQ Plus ${ }^{\circledR}$. The RPHPLC column used is a Thermo Hypersil Gold ${ }^{\circledR} 50 \times 2.1 \mathrm{~mm}$ (C18 bounded), with particles of $1.9 \mu \mathrm{m}$ diameter. Analysis was $8 \mathrm{~min}$ running with a $\mathrm{MeOH} / \mathrm{H}_{2} \mathrm{O}$ eluent gradient from 50:50 to 95:05. Silica gel 60 (70-230 mesh from Macherey-Nagel) was used for flash chromatography. Melting points were measured in open capillary tubes with Büchi apparatus and are uncorrected. ${ }^{1} \mathrm{H}$ and ${ }^{13} \mathrm{C}$ NMR spectra were recorded at room temperature in deuterated solvents on a Brüker Avance-250 instrument (250 MHz), a Brüker Avance III nanobay-300 MHz or a Brüker Avance III nanobay-400 MHz. Chemical shifts $(\delta)$ are reported in parts per million (ppm) relative to TMS as internal standard or relative to the solvent $\left[{ }^{1} \mathrm{H}: \delta(\mathrm{DMSO})=2.50 \mathrm{ppm}, \delta\left(\mathrm{CDCl}_{3}\right)=7.26\right.$ ppm; $\left.{ }^{13} \mathrm{C}: \delta(\mathrm{DMSO})=39.52 \mathrm{ppm}, \delta\left(\mathrm{CDCl}_{3}\right)=77.16 \mathrm{ppm}\right]$. Data are reported as follows: chemical shift, multiplicity $(\mathrm{s}=$ singulet, $\mathrm{d}=$ doublet, $\mathrm{t}=$ triplet, $\mathrm{q}=$ quartet, $\mathrm{dd}=$ doublet of doublets, $\mathrm{m}=$ multiplet, and $\mathrm{bs}=$ broad singlet), coupling constant in Hertz, and integration. Two-dimensional spectroscopy (HSQC and HMBC) was used to assist in the assignment and the data are not reported. Accurate mass measurements (HRMS) were recorded on a TOF spectrometer, realized by Spectropôle of Faculté des Sciences de Saint Jérôme, Marseille (France). Purity of tested compounds was found to be $>95 \%$ by high pressure liquid chromatography (HPLC). 
4-Bromo-1-(chloromethyl)-2-nitrobenzene (6a). Step 1: $\mathrm{BH}_{3}(1.0 \mathrm{M}$ solution in THF, $7 \mathrm{~mL}, 7$ mmol) was slowly added to a solution of 4-bromo-2-nitrobenzoic acid (2 $\mathrm{g}, 8.1 \mathrm{mmol})$ in anhydrous THF $(10 \mathrm{~mL})$ at $0{ }^{\circ} \mathrm{C}$. The mixture was stirred at room temperature for 3 days. The mixture was quenched by dropwise addition of a saturated aqueous solution of $\mathrm{NaHCO}_{3}$. Then, the mixture was extracted with EtOAc. The combined organic layers were washed with water and brine, dried over $\mathrm{Na}_{2} \mathrm{SO}_{4}$, filtered off and concentrated under reduced pressure to afford the pure (4-bromo-2-nitrophenyl)methanol (1.3 g, $5.7 \mathrm{mmol}, 71 \%)$ as a beige solid. Step 2: To a solution of (4-bromo-2-nitrophenyl)methanol (1.3 g, $5.7 \mathrm{mmol})$ in $\mathrm{CH}_{2} \mathrm{Cl}_{2}(10 \mathrm{~mL})$ was added a few drops of triethylamine, and $\mathrm{SOCl}_{2}(0.5 \mathrm{~mL}, 6.7 \mathrm{mmol})$ at $0{ }^{\circ} \mathrm{C}$. After stirring overnight at room temperature, the reaction was quenched by addition of a aqueous solution $\mathrm{NaOH} 2 \mathrm{~N}$. The mixture was washed with water and brine, dried over $\mathrm{Na}_{2} \mathrm{SO}_{4}$, filtered off and concentrated under reduced pressure. After purification by column chromatography on silica gel (Petroleum ether/EtOAc 8:2), the pure product 6 a $(1,3 \mathrm{~g}, 5,2 \mathrm{mmol}, 92 \%)$ was obtained as a beige solid. ${ }^{1} \mathrm{H}$ NMR $\left(250 \mathrm{MHz}, \mathrm{CDCl}_{3}\right) \delta 8.21(\mathrm{~d}, J=1.7 \mathrm{~Hz}, 1 \mathrm{H}), 7.77(\mathrm{dd}, J=8.3,1.7 \mathrm{~Hz}, 1 \mathrm{H}) .7 .59(\mathrm{~d}, J=$ $8.3 \mathrm{~Hz}, 1 \mathrm{H}), 4.93\left(\mathrm{~s}, 2 \mathrm{H}, \mathrm{CH}_{2}\right) .{ }^{13} \mathrm{C} \mathrm{NMR}\left(62.5 \mathrm{MHz}, \mathrm{CDCl}_{3}\right) \delta 148.4\left(\mathrm{C}_{\mathrm{IV}, \mathrm{Ar}}\right), 136.9\left(\mathrm{CH}_{\mathrm{Ar}}\right)$, 133.0 $\left(\mathrm{CH}_{\mathrm{Ar}}\right), 131.6\left(\mathrm{C}_{\mathrm{IV}, \mathrm{Ar}}\right), 128.4\left(\mathrm{CH}_{\mathrm{Ar}}\right), 122.8\left(\mathrm{C}_{\mathrm{IV}, \mathrm{Ar}}\right), 42.3\left(\mathrm{CH}_{2}\right)$.

4-Chloro-1-(chloromethyl)-2-nitrobenzene (6b). Following the same procedure used to prepare 6a, the crude product was prepared with 4-chloro-2-nitrobenzoic acid (2.3 g, 11.4 mmol). After purification by column chromatography on silica gel $\left(\mathrm{CH}_{2} \mathrm{Cl}_{2}\right)$, the pure product $\mathbf{6 b}$ $(2.14 \mathrm{~g}, 10.4 \mathrm{mmol}, 92 \%)$ was obtained as brown oil. ${ }^{1} \mathrm{H} \mathrm{NMR}\left(250 \mathrm{MHz}, \mathrm{CDCl}_{3}\right) \delta 8.00(\mathrm{~d}, J=$ $1.6 \mathrm{~Hz}, 1 \mathrm{H}), 7,65-7,57(\mathrm{~m}, 2 \mathrm{H}), 4,91\left(\mathrm{~s}, 2 \mathrm{H}, \mathrm{CH}_{2}\right) .{ }^{13} \mathrm{C}$ NMR $\left(62.5 \mathrm{MHz}, \mathrm{CDCl}_{3}\right) \delta 148,2$ $\left(\mathrm{C}_{\mathrm{IV}, \mathrm{Ar}}\right), 135,3\left(\mathrm{C}_{\mathrm{IV}, \mathrm{Ar}}\right), 133,8\left(\mathrm{CH}_{\mathrm{Ar}}\right), 132,8\left(\mathrm{CH}_{\mathrm{Ar}}\right), 131,0(\mathrm{C} \mathrm{IV}, \mathrm{Ar}), 125,4\left(\mathrm{CH}_{\mathrm{Ar}}\right), 42,2\left(\mathrm{CH}_{2}\right)$. 
4-Fluoro-1-(chloromethyl)-2-nitrobenzene (6c). Following the same procedure used to prepare 6a, the crude product was prepared with 4-fluoro-2-nitrobenzoic acid (1.3 g, $7.0 \mathrm{mmol})$. After purification by column chromatography on silica gel $\left(\mathrm{CH}_{2} \mathrm{Cl}_{2}\right)$, the pure product $\mathbf{6 c}(1.16 \mathrm{~g}, 6.1$ mmol, $89 \%)$ was obtained as green oil. ${ }^{1} \mathrm{H}$ NMR $\left(250 \mathrm{MHz}, \mathrm{CDCl}_{3}\right) \delta 7,75\left(\mathrm{dd}, J_{\mathrm{HF}}=8.2 \mathrm{~Hz}\right.$, $\left.J_{\mathrm{HH}}=2.7 \mathrm{~Hz}, 1 \mathrm{H}\right), 7,68\left(\mathrm{dd}, J_{\mathrm{HH}}=8.6 \mathrm{~Hz}, J_{\mathrm{HF}}=5.4 \mathrm{~Hz}, 1 \mathrm{H}\right), 7,40-7,33(\mathrm{~m}, 1 \mathrm{H}), 4,91(\mathrm{~s}, 2 \mathrm{H}$, $\left.\mathrm{CH}_{2}\right) .{ }^{13} \mathrm{C}$ NMR $\left(62.5 \mathrm{MHz}, \mathrm{CDCl}_{3}\right) \delta 161.9\left(\mathrm{~d},{ }^{1} J_{\mathrm{CF}}=251 \mathrm{~Hz}, \mathrm{C}_{\mathrm{IV}, \mathrm{Ar}}\right), 148.4\left(\mathrm{~d},{ }^{3} J_{\mathrm{CF}}=8 \mathrm{~Hz}\right.$, $\left.\mathrm{C}_{\mathrm{IV}, \mathrm{Ar}}\right), 133.5\left(\mathrm{~d},{ }^{3} J_{\mathrm{CF}}=8 \mathrm{~Hz}, \mathrm{CH}_{\mathrm{Ar}}\right), 128.6\left(\mathrm{~d},{ }^{4} J_{\mathrm{CF}}=4 \mathrm{~Hz}, \mathrm{C}_{\mathrm{IV}, \mathrm{Ar}}\right), 121.1\left(\mathrm{~d},{ }^{2} J_{\mathrm{CF}}=21 \mathrm{~Hz}, \mathrm{CH}_{\mathrm{Ar}}\right)$, $113.0\left(\mathrm{~d},{ }^{2} J_{\mathrm{CF}}=27 \mathrm{~Hz}, \mathrm{CH}_{\mathrm{Ar}}\right), 42.2\left(\mathrm{CH}_{2}\right)$.

Methyl 4-(chloromethyl)-3-nitrobenzoate (6d). Following the same procedure used to prepare 6a, 4-(methoxycarbonyl)-2-nitrobenzoic acid (1.0 g, $4.4 \mathrm{mmol})$ was used to obtain the pure product $6 \mathbf{d}(903 \mathrm{mg}, 3.9 \mathrm{mmol}, 79 \%)$ as brown oil. ${ }^{1} \mathrm{H} \mathrm{NMR}\left(250 \mathrm{MHz}, \mathrm{CDCl}_{3}\right) \delta 8.61(\mathrm{~d}, J=$ $1.7 \mathrm{~Hz}, 1 \mathrm{H}), 8.24$ (dd, $J=8.0,1.7 \mathrm{~Hz}, 1 \mathrm{H}), 7.79(\mathrm{~d}, J=8.0 \mathrm{~Hz}, 1 \mathrm{H}), 4.97\left(\mathrm{~s}, 2 \mathrm{H}, \mathrm{CH}_{2}\right), 3.95(\mathrm{~s}$, 3H, $\left.\mathrm{CH}_{3}\right) .{ }^{13} \mathrm{C}$ NMR $\left(62.5 \mathrm{MHz}, \mathrm{CDCl}_{3}\right) \delta 164.5(\mathrm{C}=\mathrm{O}), 147.9\left(\mathrm{C}_{\mathrm{IV}, \mathrm{Ar}}\right), 136.7\left(\mathrm{C}_{\mathrm{IV}, \mathrm{Ar}}\right), 134.2$ $\left(\mathrm{CH}_{\mathrm{Ar}}\right), 131.9\left(\mathrm{CH}_{\mathrm{Ar}}\right), 131.6\left(\mathrm{C}_{\mathrm{IV}, \mathrm{Ar}}\right), 126.2\left(\mathrm{CH}_{\mathrm{Ar}}\right), 52.9\left(\mathrm{CH}_{3}\right), 42.4\left(\mathrm{CH}_{2}\right)$.

General procedure A for the synthesis of 9. To a glass vessel suitable for sealing with Teflon cap (for microwave vials) were added the benzyl chloride derivative 6a-6d (1 equiv.) and benzaldehyde derivative ( 3 equiv.). The vessel was capped and then evacuated and backfilled with $\mathrm{N}_{2}$ (thrice-repeated process). Anhydrous DMF $(3.5 \mathrm{~mL} / \mathrm{mmol}$ ) was introduced and the solution was vigorously stirred for $20 \mathrm{~min}$ at $-20{ }^{\circ} \mathrm{C}$. TDAE (1.06 equiv.) was added slowly and the mixture was stirred for one hour. Then, the reaction was stirred at room temperature overnight. After LC-MS analysis clearly showed that the chloride had been totally consumed, the reaction was hydrolyzed with water. The mixture was then extracted with ethyl acetate. The 
combined organic layers were washed with water and brine, dried over $\mathrm{Na}_{2} \mathrm{SO}_{4}$, filtered off, and concentrated under reduced pressure to afford the corresponding crude product.

Methyl 4-(2-hydroxy-2-(4-(pyridin-4-yl)phenyl)ethyl)-3-nitrobenzoate (9a). The crude product was prepared according to procedure A starting from $6 \mathbf{d}(100 \mathrm{mg}, 0.43 \mathrm{mmol})$ and $\mathbf{8}$ (239 mg, $1.30 \mathrm{mmol}$ ). After purification by column chromatography on silica gel $\left(\mathrm{CH}_{2} \mathrm{Cl}_{2} /\right.$ Diethyl ether 9:1 to 6:4), the pure product 9a (64 mg, $\left.0.17 \mathrm{mmol}, 39 \%\right)$ was obtained as yellow solid. m.p: $188{ }^{\circ} \mathrm{C} .{ }^{1} \mathrm{H}$ NMR $\left(400 \mathrm{MHz}, \mathrm{DMSO}_{6} \mathrm{~d}_{6}\right) \delta 8.62(\mathrm{~d}, J=6.1 \mathrm{~Hz}, 2 \mathrm{H}), 8.37(\mathrm{~d}, J$ $=1.6 \mathrm{~Hz}, 1 \mathrm{H}), 8.15(\mathrm{dd}, J=8.1,1.6 \mathrm{~Hz}, 1 \mathrm{H}), 7.79(\mathrm{~d}, J=8.2 \mathrm{~Hz}, 2 \mathrm{H}), 7.71(\mathrm{~d}, J=6.1 \mathrm{~Hz}, 2 \mathrm{H})$, $7.67(\mathrm{~d}, J=8.1 \mathrm{~Hz}, 1 \mathrm{H}), 7.47(\mathrm{~d}, J=8.2 \mathrm{~Hz}, 2 \mathrm{H}), 5.59(\mathrm{~d}, J=4.7 \mathrm{~Hz}, 1 \mathrm{H}, \mathrm{OH}), 4.88-4.84(\mathrm{~m}$, 1H), $3.90\left(\mathrm{~s}, 3 \mathrm{H}, \mathrm{CH}_{3}\right), 3.31-3.24(\mathrm{~m}, 2 \mathrm{H}) .{ }^{13} \mathrm{C}$ NMR (100 MHz, DMSO-d 6$) \delta 164.6(\mathrm{C}=\mathrm{O})$, $150.2\left(2 \mathrm{xCH}_{\mathrm{Ar}}\right), 150.0\left(\mathrm{C}_{\mathrm{IV}, \mathrm{Ar}}\right), 146.7\left(\mathrm{C}_{\mathrm{IV}, \mathrm{Ar}}\right), 146.2\left(\mathrm{C}_{\mathrm{IV}, \mathrm{Ar}}\right), 138.4\left(\mathrm{CH}_{\mathrm{Ar}}\right), 135.8\left(\mathrm{C}_{\mathrm{IV}, \mathrm{Ar}}\right), 134.2$ $\left(\mathrm{C}_{\mathrm{IV}, \mathrm{Ar}}\right), 132.4\left(\mathrm{CH}_{\mathrm{Ar}}\right), 129.0\left(\mathrm{C}_{\mathrm{IV}, \mathrm{Ar}}\right), 126.6\left(2 \mathrm{xCH}_{\mathrm{Ar}}\right), 126.4\left(2 \mathrm{xCH}_{\mathrm{Ar}}\right), 124.6\left(\mathrm{CH}_{\mathrm{Ar}}\right), 121.0$ $\left(2 \mathrm{xCH}_{\mathrm{Ar}}\right), 72.0(\mathrm{CH}), 52.6\left(\mathrm{CH}_{3}\right), 41.6\left(\mathrm{CH}_{2}\right)$. HRMS (ESI+) m/z Calc. for $\mathrm{C}_{21} \mathrm{H}_{18} \mathrm{~N}_{2} \mathrm{O}_{5}[\mathrm{M}+\mathrm{H}]^{+}$ 379.1288 , found 379.1288 .

2-(4-Bromo-2-nitrophenyl)-1-(4-(pyridin-4-yl)phenyl)ethanol (9b). The crude product was prepared according to procedure A starting from $\mathbf{6 a}(500 \mathrm{mg}, 1.99 \mathrm{mmol})$ and $\mathbf{8}(1097 \mathrm{mg}, 5.98$ mmol). After purification by column chromatography on silica gel (EtOAc/Cyclohexane 6:4 to 7:3), the pure product $9 \mathbf{b}(215 \mathrm{mg}, 0.54 \mathrm{mmol}, 27 \%)$ was obtained as light yellow solid. m.p: 177 ${ }^{\circ} \mathrm{C} .{ }^{1} \mathrm{H}$ NMR $\left(300 \mathrm{MHz}, \mathrm{DMSO}-\mathrm{d}_{6}\right) \delta 8.62(\mathrm{~d}, J=5.8 \mathrm{~Hz}, 2 \mathrm{H}), 8.11(\mathrm{~d}, J=1.8 \mathrm{~Hz}, 1 \mathrm{H}), 7.82$ $(\mathrm{dd}, J=8.3,1.8 \mathrm{~Hz}, 1 \mathrm{H}), 7.78(\mathrm{~d}, J=8.1 \mathrm{~Hz}, 2 \mathrm{H}), 7.70(\mathrm{~d}, J=5.8 \mathrm{~Hz}, 2 \mathrm{H}), 7.46(\mathrm{~d}, J=8.3 \mathrm{~Hz}$, $1 \mathrm{H}), 7.45(\mathrm{~d}, J=8.1 \mathrm{~Hz}, 2 \mathrm{H}), 5.53(\mathrm{~d}, J=4.7 \mathrm{~Hz}, 1 \mathrm{H}, \mathrm{OH}), 4.84-4.78(\mathrm{~m}, 1 \mathrm{H}), 3,23-3,10(\mathrm{~m}$, 2H). ${ }^{13} \mathrm{C}$ NMR (75 MHz, DMSO-d 6$) \delta 150.7\left(\mathrm{C}_{\mathrm{IV}, \mathrm{Ar}}\right), 150.2\left(2 \mathrm{xCH}_{\mathrm{Ar}}\right), 146.7\left(\mathrm{C}_{\mathrm{IV}, \mathrm{Ar}}\right), 146.2$ $\left(\mathrm{C}_{\mathrm{IV}, \mathrm{Ar}}\right), 135.8\left(\mathrm{C}_{\mathrm{IV}, \mathrm{Ar}}\right), 135.2\left(\mathrm{CH}_{\mathrm{Ar}}\right), 135.1\left(\mathrm{C}_{\mathrm{IV}, \mathrm{Ar}}\right), 132.3\left(\mathrm{C}_{\mathrm{IV}, \mathrm{Ar}}\right), 126.6 \quad\left(2 \times \mathrm{xH}_{\mathrm{Ar}}\right), 126.5$ 
$\left(\mathrm{C}_{\mathrm{IV}, \mathrm{Ar}}\right), 126.4\left(2 \mathrm{xCH}_{\mathrm{Ar}}\right), 121.0\left(2 \mathrm{xCH}_{\mathrm{Ar}}\right), 119.3\left(\mathrm{CH}_{\mathrm{Ar}}\right), 71.9\left(\mathrm{CH}_{\mathrm{Ar}}\right), 40.9\left(\mathrm{CH}_{2}\right)$. HRMS (ESI+) $\mathrm{m} / \mathrm{z}$ Calc. for $\mathrm{C}_{19} \mathrm{H}_{15} \mathrm{BrN}_{2} \mathrm{O}_{3}[\mathrm{M}+\mathrm{H}]^{+}$399.0339, found 399.0339.

1-(4-(1H-Pyrazol-1-yl)phenyl)-2-(4-bromo-2-nitrophenyl)ethanol (9c). The crude product was prepared according to procedure A starting from 6a $(500 \mathrm{mg}, 1.99 \mathrm{mmol})$ and $4-(1 \mathrm{H}-$ pyrazol-1-yl)benzaldehyde (1031 mg, $5.98 \mathrm{mmol})$. After purification by column chromatography on silica gel (Petroleum ether/EtOAc 7:3), the pure product 9 c $(230 \mathrm{mg}, 0.59 \mathrm{mmol}, 30 \%)$ was obtained as light orange solid. m.p: $164{ }^{\circ} \mathrm{C} .{ }^{1} \mathrm{H}$ NMR (400 MHz, DMSO-d 6 ) $\delta 8.47$ (d, $J=2.6$ $\mathrm{Hz}, 1 \mathrm{H}), 8.10(\mathrm{~d}, J=2.0 \mathrm{~Hz}, 1 \mathrm{H}), 7.82(\mathrm{dd}, J=8.3,2.0 \mathrm{~Hz}, 1 \mathrm{H}), 7.79(\mathrm{~d}, J=8.6 \mathrm{~Hz}, 2 \mathrm{H}), 7.73$ $(\mathrm{d}, J=1.5 \mathrm{~Hz}, 1 \mathrm{H}), 7.42(\mathrm{~d}, J=8.3 \mathrm{~Hz}, 1 \mathrm{H}), 7.41(\mathrm{~d}, J=8.6 \mathrm{~Hz}, 2 \mathrm{H}), 6.53(\mathrm{dd}, J=2.6,1.5 \mathrm{~Hz}$, 1H), $5.54(\mathrm{~d}, J=4,6 \mathrm{~Hz}, 1 \mathrm{H}, \mathrm{OH}), 4.80-4.76(\mathrm{~m}, 1 \mathrm{H}), 3.17-3.15(\mathrm{~m}, 2 \mathrm{H}) .{ }^{13} \mathrm{C}$ NMR $(100 \mathrm{MHz}$, DMSO-d $\mathrm{d}_{6} \delta 150.7\left(\mathrm{C}_{\mathrm{IV}, \mathrm{Ar}}\right), 142.8\left(\mathrm{C}_{\mathrm{IV}, \mathrm{Ar}}\right), 140.8\left(\mathrm{CH}_{\mathrm{Ar}}\right), 138.7\left(\mathrm{C}_{\mathrm{IV}, \mathrm{Ar}}\right), 135.2\left(\mathrm{C}_{\mathrm{IV}, \mathrm{Ar}}\right), 135.1$ $\left(\mathrm{CH}_{\mathrm{Ar}}\right), 132.3\left(\mathrm{CH}_{\mathrm{Ar}}\right), 127.6\left(\mathrm{CH}_{\mathrm{Ar}}\right), 126.7\left(2 \mathrm{xCH}_{\mathrm{Ar}}\right), 126.5\left(\mathrm{C}_{\mathrm{IV}, \mathrm{Ar}}\right), 119.4\left(\mathrm{CH}_{\mathrm{Ar}}\right), 118.0$ $\left(2 \times \mathrm{CH}_{\mathrm{Ar}}\right), 107.7\left(\mathrm{CH}_{\mathrm{Ar}}\right), 71.8(\mathrm{CH}), 40.1\left(\mathrm{CH}_{2}\right)$. HRMS (ESI+) m/z Calc. for $\mathrm{C}_{17} \mathrm{H}_{14} \mathrm{BrN}_{3} \mathrm{O}_{3}$ $[\mathrm{M}+\mathrm{H}]^{+}$388.0291, found 388.0294.

1-(4-(1H-Pyrazol-1-yl)phenyl)-2-(4-chloro-2-nitrophenyl)ethanol (9d). The crude product was prepared according to procedure A starting from $\mathbf{6 b}(200 \mathrm{mg}, 0.97 \mathrm{mmol})$ and $4-(1 \mathrm{H}-$ pyrazol-1-yl)benzaldehyde ( $251 \mathrm{mg}, 1.45 \mathrm{mmol}, 1.5$ equiv.). After purification by column chromatography on silica gel (Petroleum ether/EtOAc 8:2 to 5:5), the pure product 9d (68 $\mathrm{mg}$, $0.19 \mathrm{mmol}, 20 \%$ ) was obtained as light yellow solid. m.p: $167{ }^{\circ} \mathrm{C} .{ }^{1} \mathrm{H}$ NMR $(250 \mathrm{MHz}$, DMSO$\left.\mathrm{d}_{6}\right) \delta 8.48(\mathrm{~d}, J=2.4 \mathrm{~Hz}, 1 \mathrm{H}), 8.01(\mathrm{~d}, J=2.2 \mathrm{~Hz}, 1 \mathrm{H}), 7.79(\mathrm{~d}, J=8.4 \mathrm{~Hz}, 1 \mathrm{H}), 7.73(\mathrm{~d}, J=8.6$ Hz, 2H), 7.69 (d, $J=2.2 \mathrm{~Hz}, 1 \mathrm{H}), 7.47$ (d, $J=8.4 \mathrm{~Hz}, 1 \mathrm{H}), 7.38$ (d, $J=8.6 \mathrm{~Hz}, 2 \mathrm{H}), 6.54$ (dd, $J=$ 2.4, $2.2 \mathrm{~Hz}, 1 \mathrm{H}), 5.56(\mathrm{~d}, J=4.5 \mathrm{~Hz}, 1 \mathrm{H}, \mathrm{OH}), 4.82-4.75(\mathrm{~m}, 1 \mathrm{H}), 3.22-3.17(\mathrm{~m}, 2 \mathrm{H}) .{ }^{13} \mathrm{C} \mathrm{NMR}$ (75 MHz, DMSO-d 6$) \delta 150.5\left(\mathrm{C}_{\mathrm{IV}, \mathrm{Ar}}\right), 142.8\left(\mathrm{C}_{\mathrm{IV}, \mathrm{Ar}}\right), 140.7\left(\mathrm{CH}_{\mathrm{Ar}}\right), 138.6\left(\mathrm{C}_{\mathrm{IV}, \mathrm{Ar}}\right), 134.9\left(\mathrm{CH}_{\mathrm{Ar}}\right)$, 
$132.3\left(\mathrm{C}_{\mathrm{IV}, \mathrm{Ar}}\right), 131.9\left(\mathrm{CH}_{\mathrm{Ar}}\right), 131.5\left(\mathrm{C}_{\mathrm{IV}, \mathrm{Ar}}\right), 127.5\left(\mathrm{CH}_{\mathrm{Ar}}\right), 126.7\left(2 \mathrm{xCH}_{\mathrm{Ar}}\right), 123.7\left(\mathrm{CH}_{\mathrm{Ar}}\right), 118.0$ $\left(2 \times \mathrm{CH}_{\mathrm{Ar}}\right), 107.6\left(\mathrm{CH}_{\mathrm{Ar}}\right), 71.8(\mathrm{CH}), 40.9\left(\mathrm{CH}_{2}\right)$. HRMS $(\mathrm{ESI}+) \mathrm{m} / \mathrm{z}$ Calc. for $\mathrm{C}_{17} \mathrm{H}_{14} \mathrm{ClN}_{3} \mathrm{O}_{3}$ $[\mathrm{M}+\mathrm{H}]^{+}$344.0796, found 344.0795.

1-(4-(1H-Pyrazol-1-yl)phenyl)-2-(4-fluoro-2-nitrophenyl)ethanol (9e). The crude product was prepared according to procedure A starting from $\mathbf{6 c}(200 \mathrm{mg}, 1.05 \mathrm{mmol})$ and $4-(1 H$-pyrazol-1yl)benzaldehyde ( $273 \mathrm{mg}, 1.58 \mathrm{mmol}, 1.5$ equiv.). After purification by column chromatography on silica gel (Petroleum ether/EtOAc 8:2 to 5:5), the pure product 9e (120 mg, $0.36 \mathrm{mmol}, 35 \%)$ was obtained as light yellow solid. m.p: $145^{\circ} \mathrm{C} .{ }^{1} \mathrm{H}$ NMR $\left(250 \mathrm{MHz}, \mathrm{DMSO}-\mathrm{d}_{6}\right) \delta 8.48(\mathrm{~d}, J=$ $2.3 \mathrm{~Hz}, 1 \mathrm{H}), 7.85$ (dd, $J=8.9,2.4 \mathrm{~Hz}, 1 \mathrm{H}), 7.79(\mathrm{~d}, J=8.5 \mathrm{~Hz}, 2 \mathrm{H}), 7.73(\mathrm{~d}, J=1.5 \mathrm{~Hz}, 1 \mathrm{H})$, 7.58-7.46 (m, 2H), 7.39 (d, $J=8.5 \mathrm{~Hz}, 2 \mathrm{H}), 6.53(\mathrm{dd}, J=2.3,1.5 \mathrm{~Hz}, 1 \mathrm{H}), 5.53(\mathrm{~d}, J=4.6 \mathrm{~Hz}$, $1 \mathrm{H}, \mathrm{OH}), 4.81-4.74(\mathrm{~m}, 1 \mathrm{H}), 3.19-3.17(\mathrm{~m}, 2 \mathrm{H}) .{ }^{13} \mathrm{C}$ NMR (62.5 MHz, DMSO-d $) \delta 159.9(\mathrm{~d}$, $\left.{ }^{1} J_{\mathrm{CF}}=245 \mathrm{~Hz}, \mathrm{C}_{\mathrm{IV}, \mathrm{Ar}}\right), 150.4\left(\mathrm{~d},{ }^{3} J_{\mathrm{CF}}=8 \mathrm{~Hz}, \mathrm{C}_{\mathrm{IV}, \mathrm{Ar}}\right), 143.0\left(\mathrm{C}_{\mathrm{IV}, \mathrm{Ar}}\right), 140.8\left(\mathrm{CH}_{\mathrm{Ar}}\right), 138.7\left(\mathrm{C}_{\mathrm{IV}, \mathrm{Ar}}\right)$, $135.2\left(\mathrm{~d},{ }^{3} J_{\mathrm{CF}}=8 \mathrm{~Hz}, \mathrm{CH}_{\mathrm{Ar}}\right), 129.3\left(\mathrm{~d},{ }^{4} J_{\mathrm{CF}}=4 \mathrm{~Hz}, \mathrm{C}_{\mathrm{IV}, \mathrm{Ar}}\right), 127.6\left(\mathrm{CH}_{\mathrm{Ar}}\right), 126.7\left(2 \mathrm{xCH}_{\mathrm{Ar}}\right), 119.8$ $\left(\mathrm{d},{ }^{2} J_{\mathrm{CF}}=21 \mathrm{~Hz}, \mathrm{CH}_{\mathrm{Ar}}\right), 118.0\left(2 \mathrm{xCH}_{\mathrm{Ar}}\right), 111.5\left(\mathrm{~d},{ }^{2} J_{\mathrm{CF}}=26 \mathrm{~Hz}, \mathrm{CH}_{\mathrm{Ar}}\right), 107.8\left(\mathrm{CH}_{\mathrm{Ar}}\right), 72.0(\mathrm{CH})$, $40.9\left(\mathrm{CH}_{2}\right)$. HRMS (ESI+) m/z Calc. for $\mathrm{C}_{17} \mathrm{H}_{14} \mathrm{FN}_{3} \mathrm{O}_{3}[\mathrm{M}+\mathrm{H}]^{+}$328.1092, found 328.1090.

1-(4-(1H-1,2,4-Triazol-1-yl)phenyl)-2-(4-bromo-2-nitrophenyl)ethanol (9f). The crude product was prepared according to procedure A starting from 6a (500 mg, $1.99 \mathrm{mmol})$ and 4(1H-1,2,4-triazol-1-yl)benzaldehyde (1037 mg, $5.98 \mathrm{mmol})$. After purification by column chromatography on silica gel (EtOAc/Petroleum ether 8:2), the pure product 9f (101 mg, 0.26 mmol, $13 \%)$ was obtained as yellow solid. m.p: $192{ }^{\circ} \mathrm{C} .{ }^{1} \mathrm{H}$ NMR $(250 \mathrm{MHz}$, DMSO-d 6 ) $\delta 9.29$ (s, 1H), $8.23(\mathrm{~s}, 1 \mathrm{H}), 8.11(\mathrm{~d}, J=2,1 \mathrm{~Hz}, 1 \mathrm{H}), 7.83(\mathrm{dd}, J=8.3,2.1 \mathrm{~Hz}, 1 \mathrm{H}), 7.82(\mathrm{~d}, J=8.6 \mathrm{~Hz}$ 2H), 7.47 (d, $J=8.6 \mathrm{~Hz}, 2 \mathrm{H}), 7,42(\mathrm{~d}, J=8.3 \mathrm{~Hz}, 1 \mathrm{H}), 5,61(\mathrm{~d}, J=4.7 \mathrm{~Hz}, 1 \mathrm{H}, \mathrm{OH}), 4.84-4.77$ (m, 1H), 3.18-3.15 (m, 2H). ${ }^{13} \mathrm{C}$ NMR (100 MHz, DMSO-d 6$) \delta 152.3\left(\mathrm{CH}_{\mathrm{Ar}}\right), 150.7\left(\mathrm{C}_{\mathrm{IV}, \mathrm{Ar}}\right)$, 
$144.6\left(\mathrm{CH}_{\mathrm{Ar}}\right), 142.2\left(\mathrm{C}_{\mathrm{IV}, \mathrm{Ar}}\right), 135.6\left(\mathrm{C}_{\mathrm{IV}, \mathrm{Ar}}\right), 135.2\left(\mathrm{C}_{\mathrm{IV}, \mathrm{Ar}}\right), 135.1\left(\mathrm{CH}_{\mathrm{Ar}}\right), 132.2\left(\mathrm{CH}_{\mathrm{Ar}}\right), 126.9$ $\left(2 \mathrm{xCH}_{\mathrm{Ar}}\right), 126.5\left(\mathrm{C}_{\mathrm{IV}, \mathrm{Ar}}\right), 119.4\left(\mathrm{CH}_{\mathrm{Ar}}\right), 119.1\left(2 \mathrm{xCH}_{\mathrm{Ar}}\right), 71.7(\mathrm{CH}), 40.9\left(\mathrm{CH}_{2}\right)$. HRMS (ESI+) $\mathrm{m} / \mathrm{z}$ Calc. for $\mathrm{C}_{16} \mathrm{H}_{13} \mathrm{BrN}_{4} \mathrm{O}_{3}[\mathrm{M}+\mathrm{H}]^{+}$389.0244, found 389.0242.

General procedure B for the synthesis of $10 a-10 c$. In a sealed glass vial were introduced the brominated derivative (1 equiv.), boronic acid derivative (2 equiv.), $\mathrm{Pd}\left(\mathrm{PPh}_{3}\right)_{2} \mathrm{Cl}_{2}(3 \mathrm{~mol} \%$ ), and $\mathrm{K}_{2} \mathrm{CO}_{3}$ (2 equiv.). The vessel was capped and then, evacuated and backfilled with $\mathrm{N}_{2}$ (process repeated 3X). The dioxane $(8 \mathrm{~mL} / \mathrm{mmol})$ was introduced and the solution was heated at $80{ }^{\circ} \mathrm{C}$ overnight. After cooling, the mixture was extracted with ethyl acetate. The combined organic layers were washed with water and brine, dried over $\mathrm{Na}_{2} \mathrm{SO}_{4}$, filtered off, and concentrated under reduced pressure to afford the corresponding crude product 10a-10c.

2-(2-Nitro-4-(thiophen-2-yl)phenyl)-1-(4-(pyridin-4-yl)phenyl)ethanol (10a). The crude product was prepared according to procedure B starting from $\mathbf{9 b}(80 \mathrm{mg}, 0.20 \mathrm{mmol})$ and thiophen-2-ylboronic acid (52 $\mathrm{mg}, 0.40 \mathrm{mmol})$. After purification by column chromatography on silica gel (Petroleum ether/EtOAc 7:3), the pure product 10a $(53 \mathrm{mg}, 0.13 \mathrm{mmol}, 66 \%)$ was obtained as light yellow solid. m.p: $217{ }^{\circ} \mathrm{C} .{ }^{1} \mathrm{H}$ NMR (300 MHz, DMSO-d 6$) \delta 8.62$ (d, $J=3.4$ $\mathrm{Hz}, 2 \mathrm{H}), 8.13(\mathrm{~s}, 1 \mathrm{H}), 7.90-7.64(\mathrm{~m}, 7 \mathrm{H}), 7.53-7.46(\mathrm{~m}, 3 \mathrm{H}), 7.19-7.17(\mathrm{~m}, 1 \mathrm{H}), 5.53(\mathrm{~d}, J=4.9$ $\mathrm{Hz}, 1 \mathrm{H}, \mathrm{OH}), 4.89-4.79(\mathrm{~m}, 1 \mathrm{H}), 3.26-3.13(\mathrm{~m}, 2 \mathrm{H}) .{ }^{13} \mathrm{C}$ NMR $\left(75 \mathrm{MHz}, \mathrm{DMSO}-\mathrm{d}_{6}\right) \delta 150.6$ $\left(\mathrm{C}_{\mathrm{IV}, \mathrm{Ar}}\right), 150.2\left(2 \mathrm{xCH}_{\mathrm{Ar}}\right), 146.7\left(\mathrm{C}_{\mathrm{IV}, \mathrm{Ar}}\right), 146.4\left(\mathrm{C}_{\mathrm{IV}, \mathrm{Ar}}\right), 140.6\left(\mathrm{CH}_{\mathrm{Ar}}\right), 135.7\left(\mathrm{C}_{\mathrm{IV}, \mathrm{Ar}}\right), 134.1$ $\left(\mathrm{C}_{\mathrm{IV}, \mathrm{Ar}}\right), 133.2\left(\mathrm{CH}_{\mathrm{Ar}}\right), 131.8\left(\mathrm{C}_{\mathrm{IV}, \mathrm{Ar}}\right), 128.9\left(\mathrm{C}_{\mathrm{IV}, \mathrm{Ar}}\right), 128.7\left(\mathrm{CH}_{\mathrm{Ar}}\right), 126.9\left(\mathrm{CH}_{\mathrm{Ar}}\right), 126.5$ $\left(2 \mathrm{xCH}_{\mathrm{Ar}}\right), 126.4\left(2 \mathrm{xCH}_{\mathrm{Ar}}\right), 125.3\left(\mathrm{CH}_{\mathrm{Ar}}\right), 121.0\left(2 \mathrm{xCH}_{\mathrm{Ar}}\right), 120.2\left(\mathrm{CH}_{\mathrm{Ar}}\right), 72.1(\mathrm{CH}), 41.3\left(\mathrm{CH}_{2}\right)$. HRMS (ESI+) m/z Calc. for $\mathrm{C}_{23} \mathrm{H}_{18} \mathrm{~N}_{2} \mathrm{O}_{3} \mathrm{~S}[\mathrm{M}+\mathrm{H}]^{+}$403.1111, found 403.1105 . 
2-(4-(Furan-2-yl)-2-nitrophenyl)-1-(4-(pyridin-4-yl)phenyl)ethanol (10b). The crude product was prepared according to procedure B starting from $\mathbf{9 b}(80 \mathrm{mg}, 0.20 \mathrm{mmol})$ and furan-2ylboronic acid (45 mg, $0.40 \mathrm{mmol}$ ). After purification by column chromatography on silica gel (Petroleum ether/EtOAc 7:3), the pure product $10 \mathrm{~b}(56 \mathrm{mg}, 0.14 \mathrm{mmol}, 73 \%)$ was obtained as orange solid. m.p: $219{ }^{\circ} \mathrm{C} .{ }^{1} \mathrm{H}$ NMR $\left(300 \mathrm{MHz}, \mathrm{DMSO}_{-} \mathrm{d}_{6}\right) \delta 8.62(\mathrm{~d}, J=5.7 \mathrm{~Hz}, 2 \mathrm{H}), 8.15(\mathrm{~d}, J$ $=1.5 \mathrm{~Hz}, 1 \mathrm{H}), 7.91(\mathrm{dd}, J=8.0,1.5 \mathrm{~Hz}, 1 \mathrm{H}), 7,81(\mathrm{~d}, J=1.7 \mathrm{~Hz}, 1 \mathrm{H}), 7.78(\mathrm{~d}, J=8.1 \mathrm{~Hz}, 2 \mathrm{H})$, $7.70(\mathrm{~d}, J=5.7 \mathrm{~Hz}, 2 \mathrm{H}), 7.52(\mathrm{~d}, J=8.0 \mathrm{~Hz}, 1 \mathrm{H}), 7.47(\mathrm{~d}, J=8.1 \mathrm{~Hz}, 2 \mathrm{H}), 7.14(\mathrm{~d}, J=3.2 \mathrm{~Hz}$, $1 \mathrm{H}), 6.65(\mathrm{dd}, J=3.2,1.7 \mathrm{~Hz}, 1 \mathrm{H}), 5.53(\mathrm{~d}, J=4,7 \mathrm{~Hz}, 1 \mathrm{H}, \mathrm{OH}), 4,88-4,82(\mathrm{~m}, 1 \mathrm{H}), 3.27-3.15$ (m, 2H). ${ }^{13} \mathrm{C}$ NMR (75 MHz, DMSO-d 6$) \delta 150.8\left(\mathrm{C}_{\mathrm{IV}, \mathrm{Ar}}\right), 150.5\left(\mathrm{C}_{\mathrm{IV}, \mathrm{Ar}}\right), 150.2\left(2 \mathrm{xCH}_{\mathrm{Ar}}\right), 146.7$ $\left(\mathrm{C}_{\mathrm{IV}, \mathrm{Ar}}\right), 146.4\left(\mathrm{C}_{\mathrm{IV}, A r}\right), 143.8\left(\mathrm{CH}_{\mathrm{Ar}}\right), 135.7\left(\mathrm{C}_{\mathrm{IV}, \mathrm{Ar}}\right), 134.0\left(\mathrm{C}_{\mathrm{IV}, \mathrm{Ar}}\right), 131.6\left(\mathrm{CH}_{\mathrm{Ar}}\right), 129.6\left(\mathrm{CH}_{\mathrm{Ar}}\right)$, $126.8\left(\mathrm{C}_{\mathrm{IV}, \mathrm{Ar}}\right), 126.5\left(2 \mathrm{xCH}_{\mathrm{Ar}}\right), 126.4\left(2 \mathrm{xCH}_{\mathrm{Ar}}\right), 121.0\left(2 \mathrm{xCH}_{\mathrm{Ar}}\right), 118.4\left(\mathrm{CH}_{\mathrm{Ar}}\right), 112.3\left(\mathrm{CH}_{\mathrm{Ar}}\right)$, $107.8\left(\mathrm{CH}_{\mathrm{Ar}}\right), 72.1(\mathrm{CH}), 41.3\left(\mathrm{CH}_{2}\right)$. HRMS $(\mathrm{ESI}+) \mathrm{m} / \mathrm{z}$ Calc. for $\mathrm{C}_{23} \mathrm{H}_{18} \mathrm{~N}_{2} \mathrm{O}_{4}[\mathrm{M}+\mathrm{H}]^{+}$ 387.1339 , found 387.1338 .

\section{2-(4-(1-Methyl-3-(trifluoromethyl)-1H-pyrazol-5-yl)-2-nitrophenyl)-1-(4-(pyridin-4-}

yl)phenyl)ethanol (10c). The crude product was prepared according to procedure B starting from $9 \mathbf{b}$ ( $80 \mathrm{mg}, 0.20 \mathrm{mmol})$ and (1-methyl-3-trifluoromethyl-1 $H$-pyrazol-5-yl)boronic acid (78 $\mathrm{mg}, 0,40 \mathrm{mmol}$ ). After purification by column chromatography on silica gel (Petroleum ether/EtOAc 5:5), the pure product $10 \mathrm{c}(73 \mathrm{mg}, 0.16 \mathrm{mmol}, 78 \%)$ was obtained as yellow solid. m.p: $151^{\circ} \mathrm{C} .{ }^{1} \mathrm{H}$ NMR (300 MHz, DMSO-d 6 ) $\delta 8.63(\mathrm{~d}, J=4.8 \mathrm{~Hz}, 2 \mathrm{H}), 8.14$ (s, 1H), 7.87 (d, $J$ $=7.5 \mathrm{~Hz}, 1 \mathrm{H}), 7.80(\mathrm{~d}, J=7.9 \mathrm{~Hz}, 2 \mathrm{H}), 7.72-7.67(\mathrm{~m}, 3 \mathrm{H}), 7.51(\mathrm{~d}, J=7.9 \mathrm{~Hz}, 2 \mathrm{H}), 7.06(\mathrm{~s}, 1 \mathrm{H})$, $5.57(\mathrm{~d}, J=4.5 \mathrm{~Hz}, 1 \mathrm{H}, \mathrm{OH}), 4.89-4.87(\mathrm{~m}, 1 \mathrm{H}), 3.97\left(\mathrm{~s}, 3 \mathrm{H}, \mathrm{CH}_{3}\right), 3.27-3.24(\mathrm{~m}, 2 \mathrm{H}) .{ }^{13} \mathrm{C} \mathrm{NMR}$ $\left(75 \mathrm{MHz}, \mathrm{DMSO}-\mathrm{d}_{6}\right) \delta 150.3\left(\mathrm{C}_{\mathrm{IV}, \mathrm{Ar}}\right), 150.2\left(2 \mathrm{xCH}_{\mathrm{Ar}}\right), 146.7\left(\mathrm{C}_{\mathrm{IV}, \mathrm{Ar}}\right), 146.4\left(\mathrm{C}_{\mathrm{IV}, \mathrm{Ar}}\right), 142.5$ $\left(\mathrm{C}_{\mathrm{IV}, \mathrm{Ar}}\right), 139.7\left(\mathrm{q},{ }^{2} J_{\mathrm{CF}}=37 \mathrm{~Hz}, \mathrm{C}_{\mathrm{IV}, \mathrm{Ar}}\right), 135.8\left(\mathrm{C}_{\mathrm{IV}, \mathrm{Ar}}\right), 133.9\left(\mathrm{C}_{\mathrm{IV}, \mathrm{Ar}}\right), 133.9\left(\mathrm{CH}_{\mathrm{Ar}}\right), 132.3\left(\mathrm{CH}_{\mathrm{Ar}}\right)$, 
$127.9\left(\mathrm{C}_{\mathrm{IV}, \mathrm{Ar}}\right), 126.6\left(2 \mathrm{XCH}_{\mathrm{Ar}}\right), 126.4\left(2 \mathrm{xCH}_{\mathrm{Ar}}\right), 124.0\left(\mathrm{CH}_{\mathrm{Ar}}\right), 121.4\left(\mathrm{q},{ }^{1} J_{\mathrm{CF}}=266 \mathrm{~Hz}, \mathrm{CF}_{3}\right)$, $121.0\left(2 \mathrm{xCH}_{\mathrm{Ar}}\right), 105.1\left(\mathrm{q},{ }^{3} J_{\mathrm{CF}}=2 \mathrm{~Hz}, \mathrm{CH}_{\mathrm{Ar}}\right), 72.1\left(\mathrm{CH}_{\mathrm{Ar}}\right), 41.3\left(\mathrm{CH}_{2}\right), 38.4\left(\mathrm{CH}_{3}\right)$. HRMS (ESI+) $\mathrm{m} / \mathrm{z}$ Calc. for $\mathrm{C}_{24} \mathrm{H}_{19} \mathrm{~F}_{3} \mathrm{~N}_{4} \mathrm{O}_{3}[\mathrm{M}+\mathrm{H}]^{+} 469.1482$, found 469.1480 .

General procedure $C$ for the synthesis of $10 \mathrm{~d}-10 \mathrm{j}$. In a sealed glass vial were introduced the brominated derivative (1 equiv.), boronic acid derivative (2 equiv.), $\mathrm{Pd}(\mathrm{dppf}) \mathrm{Cl}_{2}(5 \mathrm{~mol} \%)$, and $\mathrm{K}_{2} \mathrm{CO}_{3}$ (2 equiv.). The vessel was capped and then, evacuated and backfilled with $\mathrm{N}_{2}$ (process repeated 3X). The dioxane $(8 \mathrm{~mL} / \mathrm{mmol})$ was introduced and the solution was heated at $80{ }^{\circ} \mathrm{C}$ overnight. After cooling, the mixture was extracted with ethyl acetate. The combined organic layers were washed with water and brine, dried over $\mathrm{Na}_{2} \mathrm{SO}_{4}$, filtered off, and concentrated under reduced pressure to afford the corresponding crude product $\mathbf{1 0 d - 1 0 j}$.

\section{1-(4-(1H-Pyrazol-1-yl)phenyl)-2-(4-(1-methyl-3-(trifluoromethyl)-1 $H$-pyrazol-5-yl)-2-}

nitrophenyl)ethanol (10d). The crude product was prepared according to procedure $\mathrm{C}$ starting from 9c (94 mg, $0.24 \mathrm{mmol})$ and (1-methyl-3-trifluoromethyl-1H-pyrazol-5-yl)boronic acid (93 $\mathrm{mg}, 0.48 \mathrm{mmol}$ ). After purification by column chromatography on silica gel (Petroleum ether/EtOAc 5:5), the pure product $10 \mathrm{~d}(92 \mathrm{mg}, 0.20 \mathrm{mmol}, 84 \%)$ was obtained as white solid. m.p: $153{ }^{\circ} \mathrm{C} .{ }^{1} \mathrm{H}$ NMR $\left(300 \mathrm{MHz}, \mathrm{DMSO}_{-} \mathrm{d}_{6}\right) \delta 8.46(\mathrm{~d}, J=2.4 \mathrm{~Hz}, 1 \mathrm{H}), 8.13(\mathrm{~d}, J=1.6 \mathrm{~Hz}$, 1H), $7.86(\mathrm{dd}, J=8.0,1.6 \mathrm{~Hz}, 1 \mathrm{H}), 7.80(\mathrm{~d}, J=8.5 \mathrm{~Hz}, 2 \mathrm{H}), 7.73(\mathrm{~d}, J=1.3 \mathrm{~Hz}, 1 \mathrm{H}), 7.64(\mathrm{~d}, J$ $=8.0 \mathrm{~Hz}, 1 \mathrm{H}), 7.44(\mathrm{~d}, J=8.5 \mathrm{~Hz}, 2 \mathrm{H}), 7.06(\mathrm{~s}, 1 \mathrm{H}), 6.53(\mathrm{dd}, J=2.4,1.3 \mathrm{~Hz}, 1 \mathrm{H}), 5.54(\mathrm{~d}, J=$ $4.7 \mathrm{~Hz}, 1 \mathrm{H}, \mathrm{OH}), 4.88-4.83(\mathrm{~m}, 1 \mathrm{H}), 3.97\left(\mathrm{~s}, 3 \mathrm{H}, \mathrm{CH}_{3}\right), 3.27-3.24(\mathrm{~m}, 2 \mathrm{H}) .{ }^{13} \mathrm{C}$ NMR $(75 \mathrm{MHz}$, DMSO-d $\left._{6}\right) \delta 150.3\left(\mathrm{C}_{\mathrm{IV}, \mathrm{Ar}}\right), 143.0\left(\mathrm{C}_{\mathrm{IV}, \mathrm{Ar}}\right), 142.5\left(\mathrm{C}_{\mathrm{IV}, \mathrm{Ar}}\right), 140.7\left(\mathrm{CH}_{\mathrm{Ar}}\right), 139.6\left(\mathrm{q},{ }^{2} J_{\mathrm{CF}}=37 \mathrm{~Hz}\right.$ $\left.\mathrm{C}_{\mathrm{IV}, \mathrm{Ar}}\right), 138.7\left(\mathrm{C}_{\mathrm{IV}, \mathrm{Ar}}\right), 136.7\left(\mathrm{C}_{\mathrm{IV}, \mathrm{Ar}}\right), 133.8\left(\mathrm{CH}_{\mathrm{Ar}}\right), 132.3\left(\mathrm{CH}_{\mathrm{Ar}}\right), 127.8\left(\mathrm{C}_{\mathrm{IV}, \mathrm{Ar}}\right), 127.5\left(\mathrm{CH}_{\mathrm{Ar}}\right)$, $126.7\left(2 \mathrm{xCH}_{\mathrm{Ar}}\right), 124.0\left(\mathrm{CH}_{\mathrm{Ar}}\right), 121.4\left(\mathrm{q},{ }^{1} J_{\mathrm{CF}}=266 \mathrm{~Hz}, \mathrm{CF}_{3}\right), 118.1\left(2 \mathrm{xCH}_{\mathrm{Ar}}\right), 107.7\left(\mathrm{CH}_{\mathrm{Ar}}\right)$, 
$105.1\left(\mathrm{q},{ }^{3} J_{\mathrm{CF}}=2 \mathrm{~Hz}, \mathrm{CH}_{\mathrm{Ar}}\right), 71.9(\mathrm{CH}), 41.2\left(\mathrm{CH}_{2}\right), 38.4\left(\mathrm{CH}_{3}\right) . \mathrm{HRMS}(\mathrm{ESI}+) \mathrm{m} / \mathrm{z}$ Calc. for $\mathrm{C}_{22} \mathrm{H}_{18} \mathrm{~F}_{3} \mathrm{~N}_{5} \mathrm{O}_{3}[\mathrm{M}+\mathrm{H}]^{+}$458.1435, found 458.1435.

\section{1-(4-(1H-Pyrazol-1-yl)phenyl)-2-(4-(1-methyl-1H-pyrazol-4-yl)-2-nitrophenyl)ethanol (10e).}

The crude product was prepared according to procedure $\mathrm{C}$ starting from $9 \mathrm{c}(130 \mathrm{mg}, 0.33 \mathrm{mmol})$ and 1-methylpyrazole-4-boronic acid pinacol ester (139 $\mathrm{mg}, 0.35 \mathrm{mmol})$. After purification by column chromatography on silica gel (Petroleum ether/EtOAc 5:5 to 2:8), the pure product 10e (98 mg, $0.25 \mathrm{mmol}, 76 \%$ ) was obtained as white solid. m.p: $166{ }^{\circ} \mathrm{C} .{ }^{1} \mathrm{H}$ NMR (300 MHz, DMSO-d 6$) \delta 8.46(\mathrm{~d}, J=2.4 \mathrm{~Hz}, 1 \mathrm{H}), 8.27(\mathrm{~s}, 1 \mathrm{H}), 8.04(\mathrm{~d}, J=1.6 \mathrm{~Hz}, 1 \mathrm{H}), 7.97(\mathrm{~s}, 1 \mathrm{H}), 7,79-$ $7,76(\mathrm{~m}, 3 \mathrm{H}), 7.72(\mathrm{~d}, J=1.3 \mathrm{~Hz}, 1 \mathrm{H}), 7.41(\mathrm{~d}, J=8.5 \mathrm{~Hz}, 2 \mathrm{H}), 7.40(\mathrm{~d}, J=7.9 \mathrm{~Hz}, 1 \mathrm{H}), 6.53$ (dd, $J=2.4,1.3 \mathrm{~Hz}, 1 \mathrm{H}), 5.48(\mathrm{~d}, J=4.7 \mathrm{~Hz}, 1 \mathrm{H}, \mathrm{OH}), 4,84-4,78(\mathrm{~m}, 1 \mathrm{H}), 3.87\left(\mathrm{~s}, 3 \mathrm{H}, \mathrm{CH}_{3}\right)$, $3.17(\mathrm{~d}, J=6.4 \mathrm{~Hz}, 2 \mathrm{H}) \cdot{ }^{13} \mathrm{C}$ NMR $\left(75 \mathrm{MHz}, \mathrm{DMSO}-\mathrm{d}_{6}\right) \delta 150.6\left(\mathrm{C}_{\mathrm{IV}, \mathrm{Ar}}\right), 143.1\left(\mathrm{C}_{\mathrm{IV}, \mathrm{Ar}}\right), 140.7$ $\left(\mathrm{CH}_{\mathrm{Ar}}\right), 138.6\left(\mathrm{C}_{\mathrm{IV}, \mathrm{Ar}}\right), 136.4\left(\mathrm{CH}_{\mathrm{Ar}}\right), 133.7\left(\mathrm{C}_{\mathrm{IV}, \mathrm{Ar}}\right), 132.2(\mathrm{C} \mathrm{IV}, \mathrm{Ar}), 129.9\left(\mathrm{CH}_{\mathrm{Ar}}\right), 128.5\left(\mathrm{CH}_{\mathrm{Ar}}\right)$, $128.4\left(\mathrm{CH}_{\mathrm{Ar}}\right), 127.5\left(\mathrm{CH}_{\mathrm{Ar}}\right), 126.7\left(2 \mathrm{xCH}_{\mathrm{Ar}}\right), 119.8\left(\mathrm{C}_{\mathrm{IV}, \mathrm{Ar}}\right), 119.6\left(\mathrm{CH}_{\mathrm{Ar}}\right), 118.0\left(2 \mathrm{xCH}_{\mathrm{Ar}}\right), 107.6$ $\left(\mathrm{CH}_{\mathrm{Ar}}\right), 72.1(\mathrm{CH}), 41.3\left(\mathrm{CH}_{2}\right), 38.7\left(\mathrm{CH}_{3}\right)$. HRMS $(\mathrm{ESI}+) \mathrm{m} / \mathrm{z}$ Calc. for $\mathrm{C}_{21} \mathrm{H}_{19} \mathrm{~N}_{5} \mathrm{O}_{3}[\mathrm{M}+\mathrm{H}]^{+}$ 390.1561 , found 390.1559 .

\section{1-(4-(1H-Pyrazol-1-yl)phenyl)-2-(4-(3,5-dimethylisoxazol-4-yl)-2-nitrophenyl)ethanol (10f).}

The crude product was prepared according to procedure $\mathrm{C}$ starting from $9 \mathbf{c}(100 \mathrm{mg}, 0.26 \mathrm{mmol})$ and 3,5-dimethylisoxazole-4-boronic acid pinacol ester $(115 \mathrm{mg}, 0.51 \mathrm{mmol})$. After purification by column chromatography on silica gel (Petroleum ether/EtOAc 5:5), the pure product 10 f (100 mg, $0.24 \mathrm{mmol}, 95 \%)$ was obtained as white solid. m.p: $130{ }^{\circ} \mathrm{C} .{ }^{1} \mathrm{H}$ NMR $\left(300 \mathrm{MHz}\right.$, DMSO-d $\left.\mathrm{d}_{6}\right)$ $\delta 8.46(\mathrm{~d}, J=2.4 \mathrm{~Hz}, 1 \mathrm{H}), 7.89(\mathrm{~d}, J=1.6 \mathrm{~Hz}, 1 \mathrm{H}), 7.80(\mathrm{~d}, J=8.5 \mathrm{~Hz}, 2 \mathrm{H}), 7.73(\mathrm{~d}, J=1.4 \mathrm{~Hz}$ 1H), $7.65(\mathrm{dd}, J=7.8,1.6 \mathrm{~Hz}, 1 \mathrm{H}), 7.57(\mathrm{~d}, J=7.8 \mathrm{~Hz}, 1 \mathrm{H}), 7.44(\mathrm{~d}, J=8.5 \mathrm{~Hz}, 2 \mathrm{H}), 6.53(\mathrm{dd}, J$ $=2.4,1.4 \mathrm{~Hz}, 1 \mathrm{H}), 5.51(\mathrm{~d}, J=4.7 \mathrm{~Hz}, 1 \mathrm{H}, \mathrm{OH}), 4,87-4,81(\mathrm{~m}, 1 \mathrm{H}), 3.23-3.20(\mathrm{~m}, 2 \mathrm{H}), 2.43(\mathrm{~s}$, 
3H), $2.25(\mathrm{~s}, 3 \mathrm{H}) .{ }^{13} \mathrm{C}$ NMR (75 MHz, DMSO-d 6$) \delta 166.0\left(\mathrm{C}_{\mathrm{IV}, \mathrm{Ar}}\right), 158.0\left(\mathrm{C}_{\mathrm{IV}, \mathrm{Ar}}\right), 150.4\left(\mathrm{C}_{\mathrm{IV}, \mathrm{Ar}}\right)$, $143.2\left(\mathrm{C}_{\mathrm{IV}, \mathrm{Ar}}\right), 140.7\left(\mathrm{CH}_{\mathrm{Ar}}\right), 138.6\left(\mathrm{C}_{\mathrm{IV}, \mathrm{Ar}}\right), 133.7\left(\mathrm{CH}_{\mathrm{Ar}}\right), 132.6\left(\mathrm{C}_{\mathrm{IV}, \mathrm{Ar}}\right), 132.1\left(\mathrm{C}_{\mathrm{IV}, \mathrm{Ar}}\right), 129.3$ $\left(\mathrm{CH}_{\mathrm{Ar}}\right), 127.5\left(\mathrm{CH}_{\mathrm{Ar}}\right), 126.6\left(2 \times \mathrm{XCH}_{\mathrm{Ar}}\right), 123.8\left(\mathrm{CH}_{\mathrm{Ar}}\right), 118.0\left(2 \mathrm{xCH}_{\mathrm{Ar}}\right), 114.1\left(\mathrm{C}_{\mathrm{IV}, \mathrm{Ar}}\right), 107.6$ $\left(\mathrm{CH}_{\mathrm{Ar}}\right), 71.9(\mathrm{CH}), 41.3\left(\mathrm{CH}_{2}\right), 11.3\left(\mathrm{CH}_{3}\right), 10.3\left(\mathrm{CH}_{3}\right)$. HRMS (ESI+) m/z Calc. for $\mathrm{C}_{22} \mathrm{H}_{20} \mathrm{~N}_{4} \mathrm{O}_{4}$ $[\mathrm{M}+\mathrm{H}]^{+}$405.1557, found 405.1555.

\section{1-(4-(1H-1,2,4-Triazol-1-yl)phenyl)-2-(4-(1-methyl-3-(trifluoromethyl)-1H-pyrazol-5-yl)-2-}

nitrophenyl)ethanol (10g). The crude product was prepared according to procedure $\mathrm{C}$ starting from $9 f(90 \mathrm{mg}, 0.23 \mathrm{mmol})$ and (1-methyl-3-trifluoromethyl-1H-pyrazol-5-yl)boronic acid (90 $\mathrm{mg}, 0.46 \mathrm{mmol}$ ). After purification by column chromatography on silica gel (EtOAc), the pure product $10 \mathrm{~g}(86 \mathrm{mg}, 0.19 \mathrm{mmol}, 82 \%)$ was obtained as white solid. m.p: $116{ }^{\circ} \mathrm{C} .{ }^{1} \mathrm{H}$ NMR $(400$ MHz, DMSO-d 6$) \delta 9.28(\mathrm{~s}, 1 \mathrm{H}), 8.23(\mathrm{~s}, 1 \mathrm{H}), 8.14(\mathrm{~d}, J=1.8 \mathrm{~Hz}, 1 \mathrm{H}), 7.88(\mathrm{dd}, J=8.1,1.8 \mathrm{~Hz}$, 1H), $7.84(\mathrm{~d}, J=8.6 \mathrm{~Hz}, 2 \mathrm{H}), 7.66(\mathrm{~d}, J=8.1 \mathrm{~Hz}, 1 \mathrm{H}), 7.52(\mathrm{~d}, J=8.6 \mathrm{~Hz}, 2 \mathrm{H}), 7.07(\mathrm{~s}, 1 \mathrm{H})$, $5.62(\mathrm{~d}, J=4.7 \mathrm{~Hz}, 1 \mathrm{H}, \mathrm{OH}), 4.90-4.86(\mathrm{~m}, 1 \mathrm{H}), 3.97(\mathrm{~s}, 3 \mathrm{H}), 3.30-3.21(\mathrm{~m}, 2 \mathrm{H}) .{ }^{13} \mathrm{C}$ NMR $(100$ MHz, DMSO-d 6$) \delta 152.3\left(\mathrm{CH}_{\mathrm{Ar}}\right), 150.3\left(\mathrm{C}_{\mathrm{IV}, \mathrm{Ar}}\right), 144.8\left(\mathrm{CH}_{\mathrm{Ar}}\right), 142.5\left(\mathrm{C}_{\mathrm{IV}, \mathrm{Ar}}\right), 142.2\left(\mathrm{C}_{\mathrm{IV}, \mathrm{Ar}}\right)$, $139.6\left(\mathrm{q},{ }^{2} J_{\mathrm{CF}}=37 \mathrm{~Hz}, \mathrm{C}_{\mathrm{IV}, \mathrm{Ar}}\right), 135.7\left(\mathrm{C}_{\mathrm{IV}, \mathrm{Ar}}\right), 133.9\left(\mathrm{C}_{\mathrm{IV}, \mathrm{Ar}}\right), 133.8\left(\mathrm{CH}_{\mathrm{Ar}}\right), 132.3\left(\mathrm{CH}_{\mathrm{Ar}}\right), 127.9$ $\left(\mathrm{C}_{\mathrm{IV}, \mathrm{Ar}}\right), 126.9\left(2 \mathrm{xCH}_{\mathrm{Ar}}\right), 124.1\left(\mathrm{CH}_{\mathrm{Ar}}\right), 121.4\left(\mathrm{q},{ }^{1} J_{\mathrm{CF}}=266 \mathrm{~Hz}, \mathrm{CF}_{3}\right), 120.1\left(2 \mathrm{xCH}_{\mathrm{Ar}}\right), 105.2(\mathrm{q}$, $\left.{ }^{3} J_{\mathrm{CF}}=2 \mathrm{~Hz}, \mathrm{CH}_{\mathrm{Ar}}\right), 71.9(\mathrm{CH}), 41.2\left(\mathrm{CH}_{2}\right), 38.5\left(\mathrm{CH}_{3}\right)$. HRMS (ESI+) m/z Calc. for $\mathrm{C}_{21} \mathrm{H}_{17} \mathrm{~F}_{3} \mathrm{~N}_{6} \mathrm{O}_{3}[\mathrm{M}+\mathrm{H}]^{+}$459.1387, found 459.1385.

\section{1-(4-(1H-1,2,4-Triazol-1-yl)phenyl)-2-(4-(1-methyl-1H-pyrazol-4-yl)-2-nitrophenyl)ethanol}

(10h). The crude product was prepared according to procedure C starting from 9 f $(90 \mathrm{mg}, 0.23$ mmol) and 1-methylpyrazole-4-boronic acid pinacol ester (96 mg, $0.46 \mathrm{mmol})$. After purification by column chromatography on silica gel $(100 \%$ EtOAc to EtOAc/MeOH $(98: 2))$, the pure product 10h $(86 \mathrm{mg}, 0.22 \mathrm{mmol}, 96 \%)$ was obtained as yellow solid. m.p: $189^{\circ} \mathrm{C} .{ }^{1} \mathrm{H}$ NMR $(300$ 
MHz, DMSO-d $) \delta 9.26(\mathrm{~s}, 1 \mathrm{H}), 8.28(\mathrm{~s}, 1 \mathrm{H}), 8.22(\mathrm{~s}, 1 \mathrm{H}), 8.05(\mathrm{~s}, 1 \mathrm{H}), 7.97(\mathrm{~s}, 1 \mathrm{H}), 7.80(\mathrm{~d}, J=$ $8.2 \mathrm{~Hz}, 2 \mathrm{H}), 7.78(\mathrm{~d}, J=8.0 \mathrm{~Hz}, 1 \mathrm{H}), 7.47(\mathrm{~d}, J=8.2 \mathrm{~Hz}, 2 \mathrm{H}), 7.40(\mathrm{~d}, J=8.0 \mathrm{~Hz}, 1 \mathrm{H}), 5.54(\mathrm{~d}$, $J=4.6 \mathrm{~Hz}, 1 \mathrm{H}, \mathrm{OH}), 4.87-4.81(\mathrm{~m}, 1 \mathrm{H}), 3.87(\mathrm{~s}, 3 \mathrm{H}), 3.17(\mathrm{~d}, J=6,1 \mathrm{~Hz}, 2 \mathrm{H}) .{ }^{13} \mathrm{C}$ NMR $(75$ MHz, DMSO-d 6$) \delta 152.2\left(\mathrm{CH}_{\mathrm{Ar}}\right), 150.6\left(\mathrm{C}_{\mathrm{IV}, \mathrm{Ar}}\right), 144.9\left(\mathrm{CH}_{\mathrm{Ar}}\right), 142.1\left(\mathrm{C}_{\mathrm{IV}, \mathrm{Ar}}\right), 136.4\left(\mathrm{CH}_{\mathrm{Ar}}\right)$, $135.6\left(\mathrm{C}_{\mathrm{IV}, \mathrm{Ar}}\right), 133.7\left(\mathrm{C}_{\mathrm{IV}, \mathrm{Ar}}\right), 132.3\left(\mathrm{C}_{\mathrm{IV}, \mathrm{Ar}}\right), 129.8\left(\mathrm{CH}_{\mathrm{Ar}}\right), 128.5\left(\mathrm{CH}_{\mathrm{Ar}}\right), 128.5\left(\mathrm{CH}_{\mathrm{Ar}}\right), 126.9$ $\left(2 \mathrm{XCH}_{\mathrm{Ar}}\right), 119.8\left(\mathrm{C}_{\mathrm{IV}, \mathrm{Ar}}\right), 119.6\left(\mathrm{CH}_{\mathrm{Ar}}\right), 119.0\left(2 \mathrm{xCH}_{\mathrm{Ar}}\right), 72.0(\mathrm{CH}), 41.2\left(\mathrm{CH}_{2}\right), 39.2\left(\mathrm{CH}_{3}\right)$. HRMS (ESI+) m/z Calc. for $\mathrm{C}_{20} \mathrm{H}_{18} \mathrm{~N}_{6} \mathrm{O}_{3}[\mathrm{M}+\mathrm{H}]^{+}$391.1513, found 391.1513 .

\section{1-(4-(1H-1,2,4-Triazol-1-yl)phenyl)-2-(4-(3,5-dimethylisoxazol-4-yl)-2-nitrophenyl)ethanol}

(10i). The crude product was prepared according to procedure $\mathrm{C}$ starting from 9 f $(90 \mathrm{mg}, 0.23$ $\mathrm{mmol}$ ) and 3,5-dimethylisoxazole-4-boronic acid pinacol ester (103 $\mathrm{mg}, 0.46 \mathrm{mmol})$. After purification by column chromatography on silica gel (100\% EtOAc), the pure product $10 \mathbf{i}$ (50 mg, $0.12 \mathrm{mmol}, 54 \%$ ) was obtained as yellow solid. m.p: $153{ }^{\circ} \mathrm{C} .{ }^{1} \mathrm{H}$ NMR (300 MHz, DMSOd 6$) \delta 9.26(\mathrm{~s}, 1 \mathrm{H}), 8.22(\mathrm{~s}, 1 \mathrm{H}), 7.90(\mathrm{~d}, J=1.5 \mathrm{~Hz}, 1 \mathrm{H}), 7.82(\mathrm{~d}, J=8.5 \mathrm{~Hz}, 2 \mathrm{H}), 7.66(\mathrm{dd}, J=$ 7.9, $1.5 \mathrm{~Hz}, 1 \mathrm{H}), 7.59$ (d, $J=7.9 \mathrm{~Hz}, 1 \mathrm{H}), 7.51$ (d, $J=8.5 \mathrm{~Hz}, 2 \mathrm{H}), 5.57$ (d, $J=4.7 \mathrm{~Hz}, 1 \mathrm{H}, \mathrm{OH})$, 4.90-4.85 (m, 1H), 3.26-3.16 (m, 2H), 2.43 (s, 3H), $2.25(\mathrm{~s}, 3 \mathrm{H}) .{ }^{13} \mathrm{C}$ NMR (75 MHz, DMSO-d $\left.\mathrm{d}_{6}\right)$ $\delta 166.0\left(\mathrm{C}_{\mathrm{IV}, \mathrm{Ar}}\right), 158.0\left(\mathrm{C}_{\mathrm{IV}, \mathrm{Ar}}\right), 152.3\left(\mathrm{CH}_{\mathrm{Ar}}\right), 150.4\left(\mathrm{C}_{\mathrm{IV}, \mathrm{Ar}}\right), 144.9\left(\mathrm{CH}_{\mathrm{Ar}}\right), 142.1\left(\mathrm{C}_{\mathrm{IV}, \mathrm{Ar}}\right), 135.6$ $\left(\mathrm{C}_{\mathrm{IV}, \mathrm{Ar}}\right), 133.7\left(\mathrm{CH}_{\mathrm{Ar}}\right), 132.6\left(\mathrm{C}_{\mathrm{IV}, \mathrm{Ar}}\right), 132.0\left(\mathrm{C}_{\mathrm{IV}, \mathrm{Ar}}\right), 129.4\left(\mathrm{CH}_{\mathrm{Ar}}\right), 126.9\left(2 \mathrm{xCH}_{\mathrm{Ar}}\right), 123.9\left(\mathrm{CH}_{\mathrm{Ar}}\right)$, $119.1\left(2 \mathrm{xCH}_{\mathrm{Ar}}\right), 114.1\left(\mathrm{C}_{\mathrm{IV}, \mathrm{Ar}}\right), 71.9(\mathrm{CH}), 41.2\left(\mathrm{CH}_{2}\right), 11.3\left(\mathrm{CH}_{3}\right), 10.3\left(\mathrm{CH}_{3}\right)$. HRMS (ESI+) $\mathrm{m} / \mathrm{z}$ Calc. for $\mathrm{C}_{21} \mathrm{H}_{19} \mathrm{~N}_{5} \mathrm{O}_{4}[\mathrm{M}+\mathrm{H}]^{+} 406.1510$, found 406.1506 .

1-(4-(1H-1,2,4-Triazol-1-yl)phenyl)-2-(2-nitro-4-(thiazol-5-yl)phenyl)ethanol $\quad(10 j) . \quad$ The crude product was prepared according to procedure $\mathrm{C}$ starting from $\mathbf{9 f}(108 \mathrm{mg}, 0.28 \mathrm{mmol})$ and thiazol-5-ylboronic acid pinacol ester $(133 \mathrm{mg}, 0.55 \mathrm{mmol})$. After purification by column chromatography on silica gel (100\% EtOAc to EtOAc/MeOH (98:2)), the pure product 10j (95 
mg, $0.24 \mathrm{mmol}, 88 \%)$ was obtained as white solid. m.p: $182{ }^{\circ} \mathrm{C} .{ }^{1} \mathrm{H}$ NMR $(300 \mathrm{MHz}$, DMSO-d 6 ) $\delta 9.26(\mathrm{~s}, 1 \mathrm{H}), 9.16(\mathrm{~s}, 1 \mathrm{H}), 8.47(\mathrm{~s}, 1 \mathrm{H}), 8.22(\mathrm{~s}, 1 \mathrm{H}), 8.19(\mathrm{~s}, 1 \mathrm{H}), 7.92(\mathrm{~d}, J=7.9 \mathrm{~Hz}, 1 \mathrm{H}), 7.82$ $(\mathrm{d}, J=8.0 \mathrm{~Hz}, 2 \mathrm{H}), 7.52(\mathrm{~d}, J=7.9 \mathrm{~Hz}, 1 \mathrm{H}), 7.49(\mathrm{~d}, J=8.0 \mathrm{~Hz}, 2 \mathrm{H}), 5.58(\mathrm{~d}, J=4,1 \mathrm{~Hz}, 1 \mathrm{H}$, $\mathrm{OH}), 4.88-4.84(\mathrm{~m}, 1 \mathrm{H}), 3.29-3.23(\mathrm{~m}, 2 \mathrm{H}) .{ }^{13} \mathrm{C}$ NMR $\left(75 \mathrm{MHz}, \mathrm{DMSO}-\mathrm{d}_{6}\right) \delta 154.6\left(\mathrm{CH}_{\mathrm{Ar}}\right)$, $152.3\left(\mathrm{CH}_{\mathrm{Ar}}\right), 150.6\left(\mathrm{C}_{\mathrm{IV}, \mathrm{Ar}}\right), 144.7\left(\mathrm{CH}_{\mathrm{Ar}}\right), 142.1\left(\mathrm{C}_{\mathrm{IV}, \mathrm{Ar}}\right), 140.8\left(\mathrm{C}_{\mathrm{IV}, \mathrm{Ar}}\right), 136.2\left(\mathrm{CH}_{\mathrm{Ar}}\right), 135.6$ $\left(\mathrm{C}_{\mathrm{IV}, \mathrm{Ar}}\right), 134.2\left(\mathrm{CH}_{\mathrm{Ar}}\right), 132.5\left(\mathrm{C}_{\mathrm{IV}, \mathrm{Ar}}\right), 130.3\left(\mathrm{C}_{\mathrm{IV}, \mathrm{Ar}}\right), 130.1\left(\mathrm{CH}_{\mathrm{Ar}}\right), 126.9\left(2 \mathrm{xCH}_{\mathrm{Ar}}\right), 121.4$ $\left(\mathrm{CH}_{\mathrm{Ar}}\right), 119.1\left(2 \mathrm{xCH}_{\mathrm{Ar}}\right), 71.9(\mathrm{CH}), 41.2\left(\mathrm{CH}_{2}\right)$. HRMS (ESI+) m/z Calc. for $\mathrm{C}_{19} \mathrm{H}_{15} \mathrm{~N}_{5} \mathrm{O}_{3} \mathrm{~S}$ $[\mathrm{M}+\mathrm{H}]^{+}$394.0968, found 394.0967.

Synthesis of Mosher esters 11a and 11b (Figure A, Supporting information).

Dimethylaminopyridine (DMAP) $(0.5 \mathrm{mg}, 0.0044 \mathrm{mmol})$ was added to a mixture of $\mathbf{1 0 h}$ ' or 10h" (17.2 mg, $0.044 \mathrm{mmol}),(R)$-methoxyphenylacetic acid (MPA) (7.0 mg, $0.044 \mathrm{mmol})$ and $N, N$-dicyclohexylcarbodiimide (DCC) $(9.0 \mathrm{mg}, 0.044 \mathrm{mmol})$ in anhydrous $\mathrm{CH}_{2} \mathrm{Cl}_{2}(3 \mathrm{~mL})$ under Ar stream. The reaction mixture was stirred at $25{ }^{\circ} \mathrm{C}$ for $12 \mathrm{~h}$, cooled to $0{ }^{\circ} \mathrm{C}$ and filtered. The filtrate was evaporated and purified by column chromatography on silica gel $(100 \%$ EtOAc) to furnish Mosher esters 11a and 11b.

Mosher ester 11a: Yield 65\%. ${ }^{1} \mathrm{H}$ NMR (400 MHz, DMSO-d $\left.\mathrm{d}_{6}\right) \delta 9.27(\mathrm{~s}, 1 \mathrm{H}), 8.34(\mathrm{~s}, 1 \mathrm{H}), 8.23$ (s, 1H), $8.14(\mathrm{~d}, J=1.8 \mathrm{~Hz}, 1 \mathrm{H}), 8.02(\mathrm{~s}, 1 \mathrm{H}), 7.81(\mathrm{dd}, J=8.0,1.8,1 \mathrm{H}), 7.71(\mathrm{~d}, J=8.6 \mathrm{~Hz}$, 2H), $7.44(\mathrm{~d}, J=8.1 \mathrm{~Hz}, 1 \mathrm{H}), 7.35-7.30(\mathrm{~m}, 5 \mathrm{H}), 7.18(\mathrm{~d}, J=8.6 \mathrm{~Hz}, 2 \mathrm{H}), 6.06(\mathrm{t}, J=7.5 \mathrm{~Hz}$, 1H), $4.85(\mathrm{~s}, 1 \mathrm{H}), 3.88(\mathrm{~s}, 3 \mathrm{H}), 3.19(\mathrm{~s}, 3 \mathrm{H}), 1.06(\mathrm{t}, J=6.9 \mathrm{~Hz}, 2 \mathrm{H})$.

Mosher ester 11b: Yield 73\%. ${ }^{1} \mathrm{H}$ NMR (400 MHz, DMSO-d 6 ) $\delta 9.32(\mathrm{~s}, 1 \mathrm{H}), 8.31$ (s, 1H), 8.26 (s, 1H), $8.05(\mathrm{~d}, J=1.8 \mathrm{~Hz}, 1 \mathrm{H}), 7.99(\mathrm{~s}, 1 \mathrm{H}), 7.87(\mathrm{~d}, J=8.6 \mathrm{~Hz}, 2 \mathrm{H}), 7.55-7.52(\mathrm{~m}, 3 \mathrm{H}), 7.31-$ $7.25(\mathrm{~m}, 5 \mathrm{H}), 7.11(\mathrm{~d}, J=8.1 \mathrm{~Hz}, 1 \mathrm{H}), 6.06-6.03(\mathrm{~m}, 1 \mathrm{H}), 4.92(\mathrm{~s}, 1 \mathrm{H}), 3.90(\mathrm{~s}, 3 \mathrm{H}), 3.19(\mathrm{~s}$, $3 \mathrm{H}), 1.06(\mathrm{t}, J=7.0 \mathrm{~Hz}, 2 \mathrm{H})$. 


\section{Enantioselective HPLC.}

Enantioselective HPLC analyses were performed by using stainless-steel Chiralpak IG (250 $\mathrm{mm} \times 4.6 \mathrm{~mm}$ i.d. $)$ and Chiralpak IG-3 $(250 \mathrm{~mm} \times 250 \mathrm{~mm} \times 10 \mathrm{~mm}$ i.d. $)$ (Daicel, Chemical Industries, Tokyo, Japan) columns. HPLC-grade solvents were used as supplied by Aldrich (Milan, Italy). The HPLC apparatus consisted of a PerkinElmer (Norwalk, CT, USA) 200 LC pump equipped with a 542 Rheodyne (Cotati, CA, USA) injector, a $1000 \mu \mathrm{L}$ sample loop, a HPLC Perkin-Elmer oven and a Perkin-Elmer 290 detector. The signal was acquired and processed by Clarity software (DataApex, Prague, The Czech Republic).

\section{Circular dichroism.}

The CD spectra of the enantiomers isolated on a semipreparative scale, dissolved in ethanol (concentration about $0.3 \mathrm{mg} / \mathrm{mL})$ in a quartz cell $\left(0.1 \mathrm{~cm}\right.$ path length) at $25^{\circ} \mathrm{C}$, were measured by using a Jasco (Jasco, Ishikawa-cho, Hachioji City, Tokyo, Japan) model J-700 spectropolarimeter in the 400-220 nm spectral range. The spectra were average computed over three instrumental scans, and the intensities are presented in terms of terms of ellipticity values (mdeg).

\section{Biological assays.}

Cells and virus. HeLa Rh cells were grown in DMEM (Gibco) supplemented with 10\% heatinactivated fetal bovine serum (FBS, Integro), and $0.075 \% \mathrm{NaHCO}_{3}$ (Gibco). Cells were grown at $37{ }^{\circ} \mathrm{C}$ in a $5 \% \mathrm{CO}_{2}$ incubator at $95-99 \%$ relative humidity. RV-A02, RV-A85, RV-A89, RVB14, RV-B42 and RV-B70 were kindly provided by K. Andries (Janssen Pharmaceutica, Beerse, Belgium). RV-A08 and RV-A28 were kindly provided by Michaele Schmidtke (Universitätsklinikum, Jena, Germany). All RVs were cultivated in HeLa Rh cells in the presence of $30 \mathrm{mM} \mathrm{MgCl} 2$. 
Cell-based antiviral assay. The antiviral activity of the synthesized compounds was evaluated in a cell-based antiviral assay with MTS read-out ([3-(4,5-dimethylthiazol-2-yl)-5-(3carboxymethoxyphenyl)-2-(4-sulfophenyl)-2H-tetrazolium]). In this assay, the (residual) metabolic activity of treated, infected cells was quantified, representing cell survival or reduction of virus-induced cytopathic effects (CPE), and thus the antiviral effect of a compound. Rhinovirus assays were performed in 96-well plate format, using DMEM supplemented with 2\% FBS, $0.075 \% \mathrm{NaHCO}_{3}$ and $30 \mathrm{mM} \mathrm{MgCl}$. Briefly, a serial dilution of the compound was added to cells grown to confluence in 96-well microtiter plates, followed by infection with a low virus inoculum. The cultures were incubated for 3 days at $35^{\circ} \mathrm{C}$ until complete CPE was observed in the untreated, infected virus control condition (VC). After removal of the medium from each well, $100 \mu \mathrm{L}$ of a $5 \%$ MTS-phenazine solution in phenol red-free MEM was added. Following incubation for $1 \mathrm{~h}$, raw OD values were collected using a microtiter plate reader (Safire, Tecan). Values were converted to percentage of controls and the $50 \%$ effective concentration $\left(\mathrm{EC}_{50}\right.$, defined as the concentration of compound that should offer $50 \%$ protection against virus-induced $\mathrm{CPE}$ ), was calculated from the dose-response curve using logarithmic interpolation. In addition, the assays were inspected by light microscope and the adverse effect of the compound on the cells was quantified by cell scoring, from which the $\mathrm{CC}_{50}$ (concentration at which $50 \%$ cytotoxic effect is observed) was calculated using logarithmic interpolation.

Time-of-drug addition assay. HeLa Rh cells were allowed to adhere overnight in 96-well cell culture plates. The next day, $1 \mu \mathrm{M}$ compound $10 \mathrm{e},(S)-\mathbf{1 0 e}, \mathbf{1 0 h},(R)-\mathbf{1 0 h}$ and pleconaril $\mathbf{1}$ were added 2 hours before infection, at the time of infection or at 2, 4 or 6 hours after infection with RV-B14. Virus-infected, untreated cells were used as controls. At $8 \mathrm{~h}$ post-infection, supernatans was removed and the cells were lysed using Cell-to-cDNA lysis buffer (Thermo Fisher 
Scientific). After an additional incubation at $75^{\circ} \mathrm{C}$ for $15 \mathrm{~min}$ to inactivate DNases, intracellular viral RNA was quantified by qRT-PCR (iTaq ${ }^{\mathrm{TM}}$ Universal SYBR ${ }^{\circledR}$ Green One-Step Kit, BioRad) using following primers: 5'-GAAACACGGACACCCAAAGTA-3' and 5'CGGCCCCTGAATGCGGCTAA-3' (Integrated DNA technologies) and PCR program: 10 min at $50{ }^{\circ} \mathrm{C}, 3$ min at $95{ }^{\circ} \mathrm{C}$ and 40 cycles of $15 \mathrm{~s}$ at $95^{\circ} \mathrm{C}$ and 1 min at $60^{\circ} \mathrm{C}$ (Applied Biosystems 7500 Fast Real-Time PCR system). A dilution series of gBlocks (Integrated DNA technologies) was included as standards and RNA content was quantified as genome equivalents per sample.

Resistance selection by passaging. HeLa cells grown to confluence in 24-well microtiter plate were infected with wild-type RV-B14 in the presence of $10 \mathbf{e}, 10 \mathbf{h}$ or $\mathbf{1}$ at a concentration of $4 \mathrm{x}$, $2 \mathrm{x}$ or $1 \mathrm{x}$ their in vitro $\mathrm{EC}_{50}$. When $\mathrm{CPE}$ was visible in the virus control (no compound), all the wells were scored for visible CPE. Next, the cell supernatant (diluted 1:10) was transferred to a 24-well plate with freshly seeded HeLa cells in the presence of the compound and incubated as before. After four passages, the putative resistant virus was sequenced by Sanger sequencing. Briefly, viral RNA was isolated using Nucleospin ${ }^{\odot}$ RNA virus (Macherey-Nagel). Next, a cDNA fragment covering the VP1 coding sequence was produced using a one-step RT-PCR kit (Qiagen) and RV-B14-specific primers (FP 5'-CCTTATCCAGTGCTAAACTC-3' and RP 5'GCCCGACCCCTTTCATCAC-3'). cDNA sequences were analysed by Macrogen Inc.

Micronucleus tests.

Cell cultures and metabolic activation mixture (S9 mix). Chinese Hamster Ovary cells (CHO$\mathrm{K} 1$, ATCC) were used for the micronucleus assay. They were maintained in Mc Coy's 5A medium (Sigma) supplemented with $10 \%$ foetal calf serum, $1 \mathrm{mM}$ glutamine and penicillinestreptomycine $(100 \mathrm{U} / \mathrm{ml}-10 \mu \mathrm{g} / \mathrm{ml})$ and incubated during 24 hours at $37{ }^{\circ} \mathrm{C}$ in humidified atmosphere containing $5 \% \mathrm{CO}_{2}$. The liver homogenate used for metabolic activation (S9) was 
prepared from male Sprague-Dawley rats treated with Aroclor 1254 (500 mg/kg body weight). The S9 mix used for the test was a mixture of S9 and a solution of NADPH generating factors (Mix).The final composition of the S9 mix included included 1\% S9, $0.5 \mathrm{mM}$ G6P and $0.4 \mathrm{mM}$ NADP.

Micronucleus assay on CHO-K1 cells. The capacities of test materials to induce micronuclei were assessed according to the protocol described by Kirsch-Volders et al. ${ }^{45}$ All the assays were conducted in duplicate. The CHO-K1 cells, suspended in Mac Coys'5A medium, were transferred into Labteck wells at a concentration of 100,000 cells $/ \mathrm{ml}$, and incubated for 24 hours at $37{ }^{\circ} \mathrm{C}$ in $\mathrm{CO}_{2}(5 \%)$. When the test was performed without metabolic activation, the test substances were added into cell cultures at concentrations previously defined. A negative control containing culture medium, a solvent control containing $1 \%$ DMSO and a positive control containing $0.6 \mu \mathrm{g} / \mathrm{ml}$ of mitomycin $\mathrm{C}$ were added. When the assay was performed in the presence of metabolic activation, S9 mix metabolizing mixture was added to cell cultures at a concentration of $10 \%$. Then the test substances were added to the cell cultures at concentrations previously defined. A negative control containing culture medium, a solvent control containing $1 \%$ DMSO and a positive control containing $5 \mu \mathrm{g} / \mathrm{ml}$ of benzo-a-pyrene were added. After 3 hours of incubation at $37{ }^{\circ} \mathrm{C}$ in $\mathrm{CO}_{2}(5 \%)$, the culture medium was removed, the cells were rinsed with phosphate buffered saline (PBS), and then returned to culture in McCoy's 5A medium containing $3 \mu \mathrm{g} / \mathrm{ml}$ of cytochalasin B. After a 21 -hour incubation period at $37{ }^{\circ} \mathrm{C}$, cells were rinsed with phosphate buffered saline (PBS), fixed with methanol and stained with $10 \%$ Giemsa for 20 minutes.

Analysis of results. Cells were examined under a microscope at x1000 magnification. The antiproliferative activity of test substances was estimated by counting the number of binucleated 
cells relative to the number of mononucleated cells on a total of 500 cells for each dose (250 cells counted per well). The proliferation index (Cytokinesis Blocked Proliferative Index CBPI) was calculated using the following formula:

$$
C B P I=\frac{2 * B I+M O N O}{500}
$$

$B I$ : number of binucleated cells; $M O N O$ : number of mononucleated cells

The cytostasis index (CI\%), i.e. the percentage of cell replication inhibition, was calculated

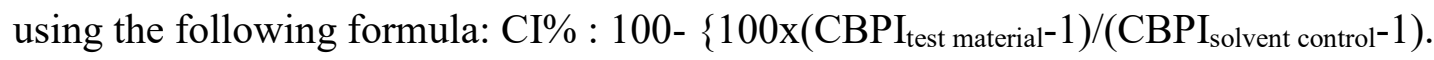

After this step, only the doses inducing a decrease of less than $55 \pm 5 \%$ of $\mathrm{CI} \%$ as compared to the negative control were taken into account for counting micronuclei. The rates of micronuclei were evaluated for the presence of independent nuclear core entities in 1000 binucleated cells per well, which corresponds to 2000 cells examined by test substance dose.

Micronuclei were identified as small nuclei well differentiated from cell nucleus, stained in the same manner and having a diameter less than one third of that of the cell nucleus. Micronuclei rates obtained for different doses of test substances were compared to the negative control by a $\mathrm{x} 2$ test. The assay was considered positive if:

a dose-response relationship was obtained between the rate of micronuclei and the doses tested,

at least one of these doses induced a statistically significant increase $(\mathrm{P}<0.05)$ in the number of micronucleated cells as compared to the negative control.

\section{Modelling and docking analysis}

All molecular modelling studies were performed on a MacPro dual $2.66 \mathrm{GHz}$ Xeon running Ubuntu 14LTS. The RV capsid structures were downloaded from PDB [http://www.rcsb.org/.]: 4PDW $;{ }^{39} 1 \mathrm{NCQ} ;{ }^{47} 3 \mathrm{VDD} .{ }^{32}$ Hydrogen atoms were added to the protein, using Maestro ${ }^{48}$ protein 
preparation wizard ${ }^{49}$ and minimized, keeping all the heavy atoms fixed until a rmsd gradient of $0.05 \mathrm{kcal} . \mathrm{mol}^{-1} . \AA^{-1}$ was reached. Ligand structures were built with Maestro and minimized using the MMFF94x force field until a rmsd gradient of $0.05 \mathrm{kcal} \cdot \mathrm{mol}^{-1} . \AA^{-1}$ was reached. The docking simulations were carried out by Plants. ${ }^{50,51}$ The homology models for studied isotypes were built by Prime ${ }^{52}$ The sequences of the VP1 proteins were available at the Uniprot database [www.uniprot.org]: RV-B70 Q7T5Z4; RV-B42 Q7T622_9ENTO; RV-A2 Q7T662_HRV2; RVA8 Q7T656_9ENTO; RV-A85 Q7T5X9_9ENTO; RV-A89 Q7T5X5_HRV89; Hr_A28 Q7T636_9ENTO Uniprot code respectively. The high identity among the references and the built models led as to avoid any further models optimizations. The images depicted in the manuscript were generated by Pymol. ${ }^{53}$

\section{ASSOCIATED CONTENT}

Supporting Information. Mosher protocol, micronucleus assays on CHO-K1 cells, illustrations of SAR studies and CD, NMR, HRMS spectra. This material is available free of charge via the Internet at http://pubs.acs.org.

\section{AUTHOR INFORMATION}

\section{Corresponding Author}

* Email: patrice.vanelle@univ-amu.fr.

\section{Author Contributions}

\# L.D.C and E.S. contributed equally.

\section{Notes}


The authors declare no competing financial interest.

\section{ACKNOWLEDGEMENT}

This work was supported by the Centre National de la Recherche Scientifique and AixMarseille Université. We thank Dr Omar Khoumeri for valuable discussions.

\section{ABBREVIATIONS}

AC, absolute configuration; AOM, Acute Otitis Media; $\mathrm{CC}_{50}, 50 \%$ cytotoxic concentration; CD, circular dichroism; CDHR-3, cadherin related family member 3; COPD, chronic obstructive pulmonary disease; CPE, cytopathic effect; $\mathrm{EC}_{50}, 50 \%$ effective concentration; HTS, High Throughput Screening; ICAM-1, intercellular adhesion molecule 1; (rac), racemic; RV, rhinovirus; SI, selectivity index; TLC, thin layer chromatography; LDL, low density lipoprotein; SAR, Structure-Activity Relationship; SET, Single-Electron Transfer; VP, viral capsid protein; $\mathrm{VC}$, virus control.

\section{REFERENCES}

(1) Jacobs, S. E.; Lamson, D. M.; St George, K.; Walsh, T. J. Human Rhinoviruses. Clin. Microbio. Rev. 2013, 26, 135-162.

(2) Van Benten, I.; Koopman, L.; Niesters, B.; Hop, W.; Van Middelkoop, B.; De Waal, L.; Van Drunen, K.; Osterhaus, A.; Neijens, H.; Fokkens, W. Predominance of rhinovirus in the nose of symptomatic and asymptomatic infants. Pediatr. Allergy Immunol. 2003, 14, 363-370. 
(3) Chonmaitree, T.; Heikkinen, T. Viruses and acute otitis media. Pediatr. Infect. Dis. J. 2000, 19, 1005-1007.

(4) Chantzi, F. M.; Papadopoulos, N. G.; Bairamis, T.; Tsiakou, M.; Bournousouzis, N.; Constantopoulos, A. G.; Liapi, G.; Xatzipsalti, M.; Kafetzis, D. A. Human rhinoviruses in otitis media with effusion. Pediatr. Allergy Immunol. 2006, 17, 514-518.

(5) Seppälä, E.; Sillanpää, S.; Nurminen, N.; Huhtala, H.; Toppari, J.; Ilonen, J.; Veijola, R.; Knip, M.; Sipilä, M.; Laranne, J.; Oikarinen, S.; Hyöty, H. Human Enterovirus and Rhinovirus infections are associated with Otitis Media in a prospective birth cohort study. J. Clin. Virol. 2016, $85,1-6$.

(6) Winther, B. Rhinovirus infections in the upper airway. Proc. Am. Thorac. Soc. 2011, 8, 7989.

(7) Pitkäranta, A.; Starck, M.; Savolainen, S.; Pöyry, T.; Suomalainen, I.; Hyypiä, T.; Carpen, O.; Vaheri, A. Rhinovirus RNA in the maxillary sinus epithelium of adults patients with acute sinusitis. Clin. Infect. Dis. 2001, 33, 909-911.

(8) Kim, H. C.; Choi, S. H.; Huh, J. W.; Sung, H.; Hong, S. B.; Lim, C. M.; Koh, Y. Different pattern of viral infections and clinical outcomes in patient with Acute Exacerbation of Chronic Obstructive Pulmonary Disease and Chronic Obstructive Pulmonary Disease with pneumonia. $J$. Med. Virol. 2016, 88, 2092-2099.

(9) Peltola, V.; Waris, M.; Österback, R.; Susi, P.; Hyypiä, T.; Ruuskanen, O. Clinical effects of rhinovirus infections. J. Clin. Virol. 2008, 43, 411-414. 
(10) Hershenson, M. B. Rhinovirus-induced exacerbations of Asthma and COPD. Scientifica 2013, 2013, 1-12.

(11) Friedlander, S. L.; Busse, W. W. The role of rhinovirus in asthma exacerbations. $J$. Allergy Cil. Immunol. 2005, 116, 267-273.

(12) Gern, J. E. How Rhinovirus Infections Cause Exacerbations of Asthma. Clin. Exp. Allergy $\mathbf{2 0 1 5}, 45,32-42$.

(13) Kraft, C. S.; Jacob, J. T.; Sears, M. H.; Burd, E. M.; Caliendo, A. M.; Lyon, G. M. Severity of human rhinovirus infection in immunocompromised adults is similar to that of 2009 H1N1 influenza. J. Clin. Microbiol. 2012, 50, 1061-1063.

(14) Mallia, P.; Message, S. D.; Gielen, V.; Contoli, M.; Gray, K.; Kebadze, T.; Aniscenko, J.; Laza-Stanca, V.; Edwards, M. R.; Slater, L.; Papi, A.; Stanciu, L. A.; Kon, O. M.; Johnson, M.; Johnston, S. L. Experimental Rhinovirus infection as a Human model of Chronic Obstructive Pulmonary Disease Exacerbation. Am. J. Respir. Crit. Care. Med. 2011, 183, 734-742.

(15) Wedzicha, J. A. Role of viruses in exacerbations of chronic obstructive pulmonary disease. Proc. Am. Thorac. Soc. 2004, 1, 115-120.

(16) Goffard, A.; Lambert, V.; Salleron, J.; Herwegh, S.; Engelmann, I.; Pinal, C.; Pin, I.; Perrez, T.; Prévotat, A.; Dewilde, A.; Delhaes, L. Virus and cystic fibrosis: Rhinoviruses are associated with exacerbations in adult patients. J. Clin. Virol. 2014, 60, 147-153. 
(17) De Almeida, M. B.; Zerbinati, R. M. ; Tateno, A. F.; Oliveira, C. M.; Romao, R. M.; Rodrigues, J. C.; Pannuti, C. S.; Da Silva Filho, L. F. V. Rhinovirus C and respiratory exacerbations in children with cystic fibrosis. Emerg. Infect. Dis. 2010, 16, 996-999.

(18) Royston, L.; Tapparel, C. Rhinoviruses and Respiratory Enteroviruses: Not as Simple as ABC. Viruses 2016, 16, doi: 10.3390/v8010016.

(19) Palmenberg, A. C.; Spiro, D.; Kuzmickas, R.; Wang, S.; Djikeng, A.; Rathe, J. A.; FraserLiggett, C. M.; Liggett, S. B. Sequencing and analyses of all known Human Rhinovirus genomes Reveal structure and evolution. Science 2009, 324, 55.

(20) Oliveira, M. A.; Zhao, R.; Lee, W-M; Kremer, M. J.; Minor, I.; Rueckert, R. R.; Diana, G. D.; Pevear, D. C.; Dutko, F. J.; McKinlay, M. A.; Rossmann, M. G. The structure of Human rhinovirus 16. Structure 1993, 1, 51-68.

(21) Hewat, E. A.; Blaas, D. Cryoelectron microscopy analysis of the structural changes associated with Human rhinovirus type 14 uncoating. J. Virol. 2004, 78, 2935-2942.

(22) Garriga, D.; Pickl-Herk, A.; Luque, D.; Wruss, J.; Castón, J. R.; Blaas, D.; Verdaguer N. Insights into minor group Rhinovirus uncoating: the X-ray structure of the HRV2 empty capsid. PLoS Pathogens 2012, 8, e1002473.

(23) Verdaguer, N.; Fita, I.; Reithmayer, M.; Moser, R.; Blaas, D. X-ray structure of a minor group human rhinovirus bound to a fragment of its cellular receptor protein. Nat. Struct. Mol. Biol. 2004, 11, 429-434. 
(24) Greve, J. M.; Davis, G.; Meyer, A. M.; Forte, C. P.; Yost, S. C.; Marlor, C. W.; Kamarck, M. E.; McClelland, A. The major Human Rhinovirus receptor is ICAM-1. Cell 1989, 56, 839847.

(25) Hofer, F.; Gruenberger, M.; Kowalski, H.; Machat, H.; Huettinger, M.; Kuechler, E.; Blaas, D. Members of the low density lipoprotein receptor family mediate cell entry of a minorgroup common cold virus. Proc. Natl. Acad. Sci. USA 1994, 91, 1839-1842.

(26) Bochkov, Y. A.; Watters, K.; Ashraf, S.; Griggs, T. F.; Devries, M. K.; Jackson, D. J.; Palmenberg, A. C.; Gern, J. E. Cadherin-related family member 3, a childhood asthma susceptibility gene product, mediates rhinovirus C binding and replication. Proc. Natl. Acad. Sci. USA 2015, 112, 5485-5490.

(27) Palmenberg, A. C. Rhinovius C, asthma, and cell surface expression of virus receptor CDHR3. J. Virol. 2017, 91, e00072-17.

(28) Katpally, U.; Smith, T. J. Pocket factors are unlikely to play a major role in the life cycle of Human rhinovirus. J. Virol. 2007, 81, 6307-6315.

(29) Patick, A. K.; Binford, S. L.; Brothers, M. A.; Jackson, R. L.; Ford, C. E.; Diem, M. D.; Maldonado, F.; Dragovich, P. S.; Zhou, R.; Prins, T. J.; Fuhrman, S. A.; Meador, J. W.; Zalman, L. S.; Matthews, D. A.; Worland, S. T. In vitro antiviral activity of AG7088, a potent inhibitor of human rhinovirus 3C protease, Antimicrob. Agents Chemother. 1999, 43, 2444-2450. 
(30) Lacroix, C.; George, S.; Leyssen, P.; Hilgenfeld, R.; Neyts, J. The Enterovirus 3C protease inhibitor SG85 efficiently blocks Rhinovirus Replication and is not cross-resistant with Rupintrivir. Antimicrob. Agents Chemother. 2015, 59, 5814-5818.

(31) De Palma, A. M.; Vliegen, I.; De Clercq, E.; Neyts, J. Selective inhibitors of Picornavirus replication. Med. Res. Rev. 2008, 6, 823-884.

(32) Feil, S. C.; Hamilton, S.; Krippner, G. Y.; Lin, B.; Luttick, A.; McConnell, D. B.; Nearn, R.; Parker, M. W.; Ryan, J.; Stanislawski, P. C.; Tucker, S. P.; Watson, K. G.; Morton, C. J. An orally available 3-ethoxybenzisoxazole capsid binder with clinical activity against Human rhinovirus. ACS Med. Chem. Lett. 2012, 3, 303-307.

(33) Makarov, V. A.; Braun, H.; Richter, M.; Riabova, O. B.; Kirchmair, J.; Kazakova, E. S.; Seidel, N.; Wutzler, P.; Schmidtke, M. Pyrazolopyrimidines: Potent inhibitors targeting the capsid of Rhino- and Enteroviruses. ChemMedChem 2015, 10, 1629-1634.

(34) Kim, J.; Jung, Y. K.; Kim, C., Shin, J. S.; Scheers, E.; Lee, J-Y; Han, S. B.; Lee, C-K; Neyts, J.; Ha, J-D; Jung, Y-S. A novel series of highly potent small molecule inhibitors of rhinovirus replication. J. Med. Chem. 2017, 13, 5472-5492.

(35) Fois, B.; Bianco, G.; Sonar, V. P.; Distinto, S.; Maccioni, E.; Meleddu, R.; Melis, C.; Marras, L.; Pompei, R.; Floris, C.; Caboni, P.; Cottiglia, F. Phenylpropenoids from Bupleurum fruticosum as anti-Human Rhinovirus species A selective capsid binders. J. Nat. Prod. 2017, 80, 2799-2806. 
(36) Diana, G. D.; Rudewicz, P.; Pevear, D. C.; Nitz, T. J.; Aldous, S. C.; Aldous, D. J.; Robinson, D. T.; Draper, T.; Dutko, F. J.; Aldi, C. Picornavirus inhibitors: Trifluoromethyl substitution provides a global protective effect against hepatic metabolism. J. Med. Chem. 1995, $38,1355-1371$.

(37) Cornebise, M. A.; Atherton, J.; Bist, S.; Butler, S.; Grebe, T. P.; Hentemann, M.; Huang, J.; Johnson, K. D.; Kawatkar, S. P.; McCrea, C.; Martin, L.; Mondal, M.; Rooney, M.; Thakur, K.; Tiong-Yip, C. L.; Wang, J.; Yu, Q. Discovery of AZN001: A broad-spectrum capsid-binding human rhinovirus inhibitor, Abstracts of Papers, 252nd ACS National Meeting \& Exposition, Philadelphia, PA, United States, August 21-25, 2016.

(38) Roche, M.; Lacroix, C.; Khoumeri, O.; Franco, D.; Neyts, J.; Terme, T.; Leyssen, P.; Vanelle, P. Synthesis, biological activity and structure-activity relationship of 4,5dimethoxybenzene derivatives inhibitor of rhinovirus 14 infection. Eur. J. Med. Chem. 2014, 76, 445-459.

(39) Lacroix, C.; Querol-Audí, J.; Roche, M.; Franco, D.; Froeyen, M.; Guerra, P.; Terme, T.; Vanelle, P.; Verdaguer, N.; Neyts, J.; Leyssen, P. A novel benzonitrile analogue inhibits rhinovirus replication. J. Antimicrob. Chem. 2014, 69, 2723-2732.

(40) Da Costa, L.; Roche, M.; Scheers, E.; Coluccia, A.; Neyts, J.; Terme, T.; Leyssen, P.; Silvestri, R.; Vanelle, P. VP1 crystal structure-guided exploration and optimization of 4,5dimethoxybenzene-based inhibitors of rhinovirus 14 infection. Eur. J. Med. Chem. 2016, 115, $453-462$. 
(41) Da Costa, L.; Scheers, E.; Coluccia, A.; Rosetti, A.; Roche, M.; Neyts, J.; Terme, T.; Cirilli, R.; Mirabelli, C.; Silvestri, R.; Vanelle, P. Heterocyclic pharmacochemistry of new rhinovirus antiviral agents: A combined computational and experimental study. Eur. J. Med. Chem. 2017, 140, 528-541.

(42) Broggi, J.; Terme, T.; Vanelle, P. Organic electron donors as powerful single-electron reducing agents in organic synthesis. Angew. Chem. Int. Ed. 2014, 53, 384-413.

(43) Lacroix, C.; Laconi, S.; Angius, F.; Coluccia, A.; Silvestri, R.; Pompei, R.; Neyts, J.; Leyssen, P. In vitro characterisation of pleconaril/pirodavir-like compound with potent activity against rhinoviruses. J. Virol. 2015, 12, 1-6.

(44) Rossmann, M. G. The structure of antiviral agents that inhibit uncoating when complexed with viral capsids. Antiviral Res. 1989, 11, 3-13.

(45) Kirsch-Volders, M.; Elhajouji, A.; Cundari, E.; Van, Hummelen P. The in vitro micronucleus test: a multi-endpoint assay to detect simultaneously mitotic delay, apoptosis, chromosome breakage, chromosome loss and non-disjunction. Mutat Res. 1997, 392, 19-30.

(46) Ledford, R. M.; Patel, N. R.; Demenczuk, T. M.; Watanyar, A.; Herbertz, T.; Collet, M.S.; Pevear, D. C. VP1 sequencing of all Human rhinovirus serotypes: insights into genus phylogeny and susceptibility to antiviral capsid-binding compounds. J. Virol. 2004, 78, 3663-3674.

(47) Zhang, Y.; Simpson, A. A.; Ledford, R. M.; Bator, C. M.; Chakravarty, S.; Skochko, G. A.; Demenczuk, T. M.; Watanyar, A.; Pevear, D. C.; Rossmann, M. G. Structural and virological 
studies of the stages of virus replication that are affected by antirhinovirus compounds. J. Virol. 2004, 78, 11061-11069.

(48) Small-Molecule Drug Discovery Suite 2015-1, Schrödinger, LLC, New York, NY, 2017.

(49) Sastry, G. M.; Adzhigirey, M.; Day, T.; Annabhimoju, R.; Sherman, W. Protein and ligand preparation: Parameters, protocols, and influence on virtual screening enrichments. $J$. Comput. Aid. Mol. Des. 2013, 27, 221-234.

(50) Korb, O.; Stutzle, T.; Exner, T.E. PLANTS: application of ant colony optimization to structure-based drug design. In Ant colony optimization and swarm intelligence, Proceedings of the 5th International Workshop, ANTS 2006 (Belgium).

(51) Dorigo, M.; Gambardella, L. M.; Birattari, M.; Martinoli, A.; Poli, R.; Stutzle, T. Lecture Notes in Computer Science (Eds) 2006, Series 4150, 247-258.

(52) Jacobson, M. P.; Pincus, D. L.; Rapp, C. S.; Day, T. J. F.; Honig, B.; Shaw, D. E.; Friesner, R. A. A Hierarchical Approach to All-Atom Protein Loop Prediction. Proteins: Structure, Function and Bioinformatics 2004, 55, 351-367.

(53) PyMOL version 1.2r1; DeLanoScientificLLC: SanCarlos, CA. http://www.pymol.org/ 
Table of Contents graphic

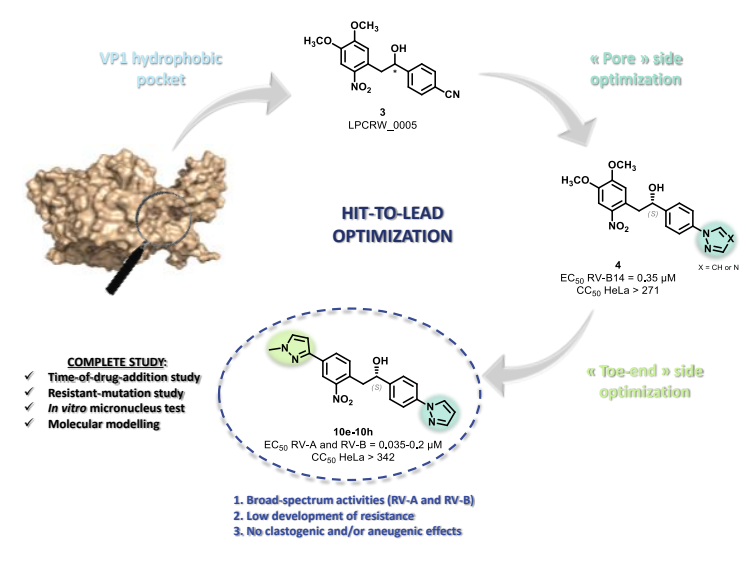

